Provided for non-commercial research and education use. Not for reproduction, distribution or commercial use.

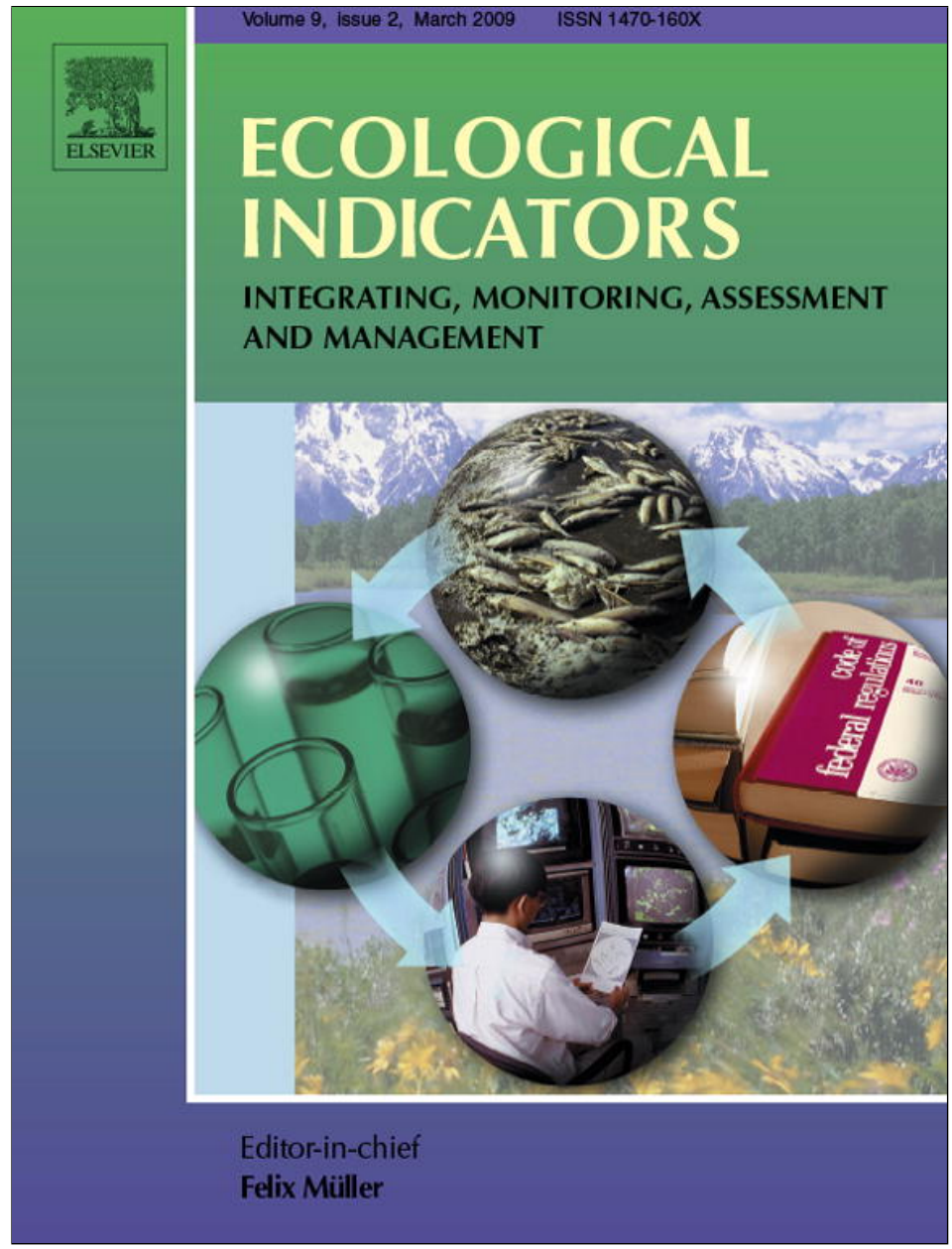

This article appeared in a journal published by Elsevier. The attached copy is furnished to the author for internal non-commercial research and education use, including for instruction at the authors institution and sharing with colleagues.

Other uses, including reproduction and distribution, or selling or licensing copies, or posting to personal, institutional or third party websites are prohibited.

In most cases authors are permitted to post their version of the article (e.g. in Word or Tex form) to their personal website or institutional repository. Authors requiring further information regarding Elsevier's archiving and manuscript policies are encouraged to visit:

http://www.elsevier.com/copyright 


\title{
A Stochastic Dynamic Methodology (StDM) for reservoir's water quality management: Validation of a multi-scale approach in a south European basin (Douro, Portugal)
}

\author{
Edna Cabecinha ${ }^{a, *}$, Rui Cortes ${ }^{b}$, Miguel Ângelo Pardal $^{c}$, João Alexandre Cabral ${ }^{a}$ \\ ${ }^{a}$ Laboratory of Applied Ecology, CITAB - Department of Biological and Environmental Engineering, \\ University of Trás-os-Montes e Alto Douro, 5000-911 Vila Real, Portugal \\ ${ }^{\mathrm{b}}$ CITAB - Department of Forestal Engineering, University of Trás-os-Montes e Alto Douro, 5000-911 Vila Real, Portugal \\ ' IMAR (Institute of Marine Research), Department of Zoology, University of Coimbra, 3004-517 Coimbra, Portugal
}

\section{A R T I C L E I N F O}

\section{Article history:}

Received 10 January 2008

Received in revised form

10 May 2008

Accepted 21 May 2008

Keywords:

Stochastic-dynamic methodology

Reservoirs

Ecological status

Phytoplankton

Ecological indicators

Environmental management

\begin{abstract}
A B S T R A C T
Worldwide aquatic ecosystems have been impacted by broad-scale environmental pressures such as agriculture, point and non-point-source pollution and land-use changes overlapping in space and time, leading to the disruption of the structure and functioning of these systems. The present paper examined the applicability of a holistic Stochastic Dynamic Methodology (StDM) in predicting the tendencies of phytoplankton communities and physicochemical conditions in reservoirs as a response to the changes in the respective watershed soil use. The case of the Douro's basin (Portugal) was used to test the StDM performance in this multi-scale approach. The StDM is a sequential modelling process developed in order to predict the ecological status of changed ecosystems, from which management strategies can be designed. The data used in the dynamic model construction included true gradients of environmental changes and was sampled from 1995 to 2004. The dynamic model developed was preceded by a conventional multivariate statistical procedure performed to discriminate the significant relationships between the selected ecological components. The model validation was based on independent data, for all the state variables considered. Overall, the simulation results are encouraging since they seem to demonstrate the StDM reliability in capturing the dynamics of the studied reservoirs. The StDM model simulations were validated for the most part of the twenty-two components selected as ecological indicators, with a performance of $50 \%$ for the physicochemical variables, $75 \%$ for the phytoplankton variables, and 100\% for the Carlson trophic state indices (TSI). This approach provides a useful starting point, as a contribution for the practical implementation of the European Water Framework Directive, allowing the development of a true integrated assessment tool for water quality management, both at the scale of the reservoir body and at the scale of the respective river watershed dynamics.
\end{abstract}

(C) 2008 Elsevier Ltd. All rights reserved.

\section{Introduction}

The reservoirs, as the main worldwide aquatic ecosystems, have been impacted by broad-scale point and non-point environmental pressures, resulting in the disposal of domestic and agricultural waste water, runoff of nutrients, organic and toxic compounds (Brazner et al., 2007; Danz et al., 2007). The land-use changes in the watershed, overlapping in space and

\footnotetext{
* Corresponding author. Tel.: +351 259350 239; fax: +351 259350480 .

E-mail address: edna@utad.pt (E. Cabecinha).

1470-160X/\$ - see front matter (C) 2008 Elsevier Ltd. All rights reserved. doi:10.1016/j.ecolind.2008.05.010
} 
time, may have considerable effects on the reservoirs. Particular negative effects are produced by changes in agricultural practices, leading to the disruption of the structure and functioning of these man-made systems (Robarts, 1985; Reynolds, 1992; Vasconcelos, 2001). In this context, any management option must take into account not only the components of the reservoir, but also the human activities within the respective watershed. Consequently, the management strategies for aquatic systems in general, and for reservoirs in particular, has an increasing need for tools capable to relate intrinsic variables with perceived external threats to the parameters of water quality that the national entities have been established to protect and/or improve. The growing need to analyse the present state of ecosystems and to monitor their rate of change, has triggered a demand for studies that explore species environment relationships and use these relationships to assess and predict changes under anthropogenic influence (Statzner et al., 2001; Simboura et al., 2005; Ekdahl et al., 2007).

Building on the long tradition of using organisms in monitoring and assessment programs, the European Commission issued a directive (European Water Framework Directive, WFD) mandating the use of different organism groups to monitor the integrity of inland waters and coastal regions. In this context, the use of adequate ecological indicators is particularly helpful in assessing the impact of environmental changes on characteristic ecological patterns (Barbour et al., 1999; Andreasen et al., 2001; Dziock et al., 2006). Therefore, key aquatic communities have been used, in some cases for decades, to evaluate water quality and ecological status of aquatic ecosystems, namely lakes and reservoirs. In this paper, the phytoplankton community and their physicochemical environment were used as ecological indicators, since they represent the base of lakes and reservoirs food webs and quickly respond to stresses and perturbations. In fact, these variables have been commonly chosen for aquatic bioassessment since they meet the following criteria (Håkanson and Peters, 1995; Moldan and Billharz, 1997; Heiskanen and Solimini, 2005): (1) are measurable, simply and inexpensively, (2) clearly interpretable and predictable by validated quantitative models, (3) internationally applicable, (4) relevant for a given environmental threat, (5) representative for the given ecosystem, and (6) comprehensible to politicians and the general public.

The WFD prescribes that European countries restore the "good ecological status" of water bodies of their aquatic systems. One way to cope with the complexity of this problematic for sound environmental management of reservoirs is to apply mathematical models of different kinds (Even et al., 2007). Therefore, ecological integrity studies have been improved by creating dynamic models that simultaneously attempt to capture the structure and the composition in systems affected by long-term environmental disturbances (Jørgensen, 1994; Costanza and Voinov, 2003; Chaloupka, 2002; Cabecinha et al., 2004, 2007; Silva-Santos et al., 2006, 2008). The application of ecological models can synthesize the pieces of ecological knowledge, emphasizing the need for a holistic view of a certain environmental problem (Jørgensen, 2001; Cabecinha et al., 2004, 2007; Silva-Santos et al., 2006, 2008). Any environmental assessment must begin with a conceptual model that includes the natural geographic and habitat setting, human activity that can potentially stress the ecosystem (e.g., agriculture), stressors resulting from that human activity (e.g., increased nutrients) and the effects of those stressors on the ecosystem (Stevenson et al., 2004). Nowadays environmental assessment is pushed to assist with land use planning decisions and projections of 'what if' scenarios at the landscape scale and, consequently, it is necessary to capture the main cause-effect relationships between human activity and ecosystem responses (Bailey et al., 2007).

Since many of the ecosystem phenomenological aspects are holistic, whole-system properties, the main vocation of the Stochastic Dynamic Methodology (StDM) recently developed is a mechanistic understanding of the holistic ecological processes, based on a statistical parameter estimation method (Santos and Cabral, 2003; Cabecinha et al., 2004; Silva-Santos et al., 2006, 2008). This recent research is based on the premise that the general statistical patterns of ecological phenomena are emergent indicia of complex ecological processes that do indeed reflect the operation of universal law-like mechanisms. The StDM is a sequential modelling process developed in order to predict the ecological status of changed ecosystems, from which management strategies can be designed. This methodology was successfully tested in several types of ecological systems, such as mountain running waters (Cabecinha et al., 2004, 2007), mediterranean agroecosystems (Santos and Cabral, 2003; Cabral et al., 2007), estuaries (Silva-Santos et al., 2006, 2008), and for simulating the impact of socioeconomic trends on threatened species (Santos et al., 2007).

The goal of the present work is to apply and extend the above principles to reservoir water quality management, and to demonstrate the potential of the StDM in the scope of the practical implementation of the WFD. Therefore, when applied as a multi-scale approach, the StDM model can be run for different levels simultaneously taking into account stochastic/ random phenomena that characterize the real ecological processes. The main objectives of this paper include not only to validate but also to demonstrate the StDM performance in capturing how expected changes at land use level will alter the reservoir water quality, namely at physicochemical and phytoplankton levels. Since the progressive tendency to degradation of reservoirs takes place in most watersheds of Northeast Portugal (Moreira et al., 2002), the Douro river basin was used as an exemplificative scenario. The hypotheses to be tested were: (1) that the selected metrics are representative of the local phytoplankton community and physicochemical environment that changes in some predictable way with the increasing of human and natural influences, and (2) that the ecosystem integrity and respective ecological status can be assessed by the state variables, assumed as important ecological indicators, used in the StDM model construction.

\section{Materials and methods}

\subsection{Study area}

This study was carried out in 11 reservoirs from the Douro river catchment (North of Portugal): Miranda (MRD), Picote 


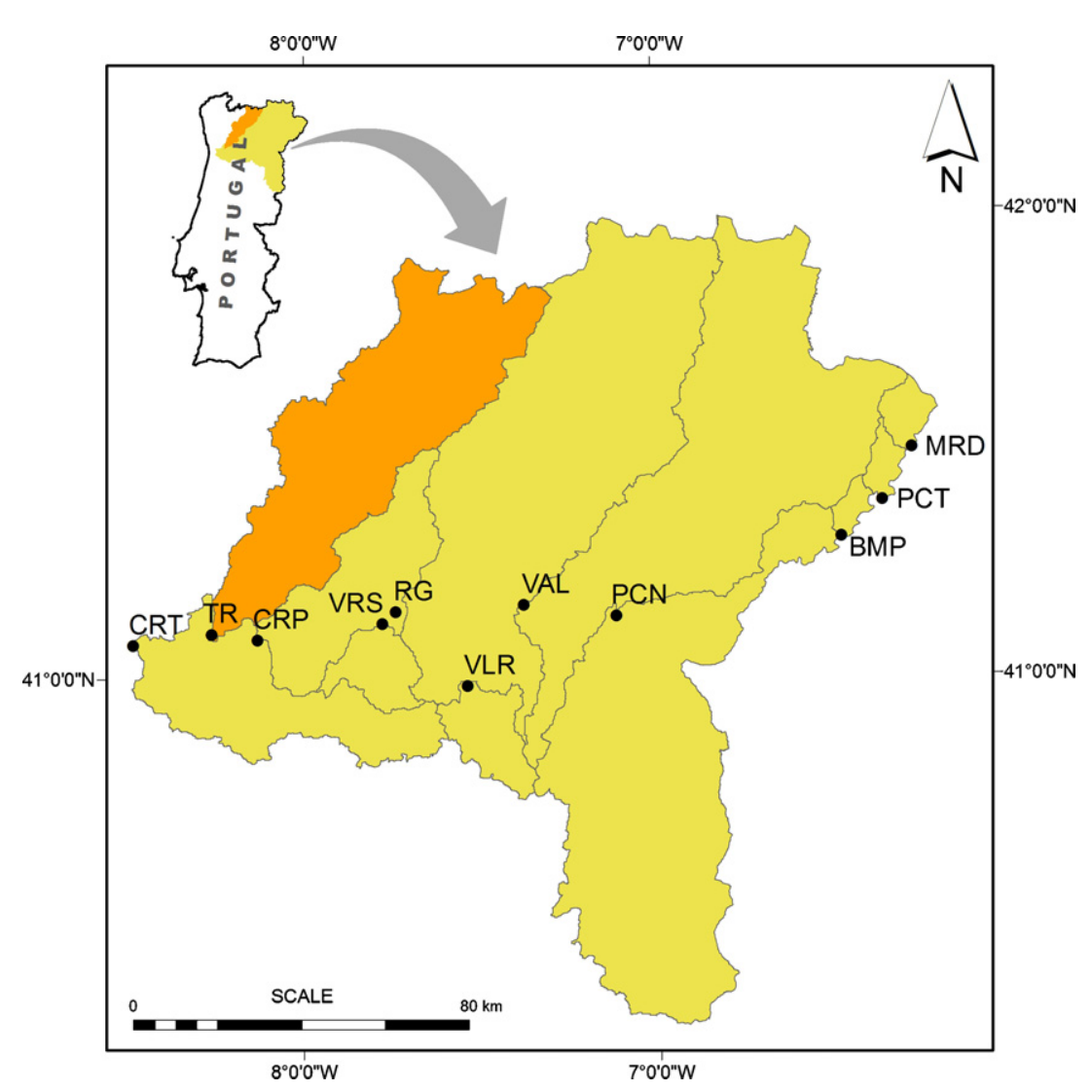

Fig. 1 - Location of the study area in the Douro river basin with the different watersheds and respective reservoirs, used as data sources in the construction of the StDM model: Crestuma (CRT), Carrapatelo (CRP), Varosa (VRS), Rágua (RG), VilarTabuaço (VLR), Valeira (VAL), Pocinho (PCN), Bemposta (BMP), Picote (PCT) and Miranda (MRD). The data from the Torrão (TR) reservoir (dashed area) was separated for validation purposes.

(PCT), Bemposta (BMP), Pocinho (PCN), Valeira (VAL), VilarTabuaço (VLR), Régua (RG), Varosa (VRS), Carrapatelo (CRP), Torrão (TR) and Crestuma (CRT) (Fig. 1). The main purpose of all these reservoirs is hydroelectric power generation, although some secondary uses are also common, such as navigation, irrigation, water supply and recreation.

The Douro River flows within the largest watershed in the Iberian Peninsula, draining $98,000 \mathrm{~km}^{2}$ (17\% of this territory). The flow of this international watershed, shared between Spain (80\%) and Portugal (20\%) and heavily regulated by 51 large dams, represents about $15 \mathrm{~km}^{3}$ of freshwater per year discharged into the Atlantic Ocean. However, the flow regime depends not only on climatic conditions but also on hydroelectric power generation needs in both countries, as well as by irrigation needs, particularly in Spain. In Portugal, the first dam on the watershed was built in 1920, but the larger dams (with more than $15 \mathrm{~m}$ of wall height) started operating only in the late 1950s. These dams are particularly concentrated in the last $350 \mathrm{~km}$ of the main river course. Altogether, large dams retain up to $1100 \mathrm{hm}^{3}$ (13\%) of water in Portuguese reservoirs and $7500 \mathrm{hm}^{3}$ on the Spanish side of the watershed (Vieira and Bordalo, 2000).

In Portugal, rainfall has a high seasonal variation, occurring $70 \%$ of the total precipitation between October and May. In Douro catchment more than $1400 \mathrm{~mm}$ /year occurred in the mountainous northern areas and less than $500 \mathrm{~mm} /$ year in the semi-arid central part of this region. This extensive geographic area represents a wide range in physical and chemical characteristics, soil use and anthropogenic pressure, including both good and poor water quality conditions. Most of the population lives in coastal areas. Therefore, many impacts associated with urbanization are present there, namely water quality problems associated with nutrient enrichment and high biochemical oxygen demand (BOD) due to industrial effluent discharges, urban development and intensive agriculture. For example, the Crestuma reservoir, located at $21.6 \mathrm{~km}$ from Douro's mouth, is the only suitable source for the production of potable water for approximately two million inhabitants of the Porto region, representing $20 \%$ of the Portuguese population.

In general, land use of the Douro basin is dominated by agricultural activities, although the high concentration of industries, mainly transformation industries and mines, is also important.

The majority of these dams are "run-of-river" reservoirs (see Table 1 for details), with very low water residence time and with the hydrological stability mostly conditioned by the short-term atmospheric conditions. The remaining dams (VLR, VRS and TR) are explored as true reservoirs, with relatively high water residence time and with variations along 
Table 1 - Codes and mean values for all the variables used in the StDM model construction and validation

\begin{tabular}{|c|c|c|c|c|c|c|c|c|c|c|c|c|}
\hline Variables & CODE & $\begin{array}{c}\text { Bemposta } \\
\text { BMP }\end{array}$ & $\begin{array}{c}\text { Carrapatelo } \\
\text { CRP }\end{array}$ & $\begin{array}{l}\text { Crestuma } \\
\text { CRT }\end{array}$ & $\begin{array}{l}\text { Miranda } \\
\text { MRD }\end{array}$ & $\begin{array}{l}\text { Pocinho } \\
\text { PCN }\end{array}$ & $\begin{array}{l}\text { Picote } \\
\text { PCT }\end{array}$ & $\begin{array}{l}\text { Régua } \\
\text { RG }\end{array}$ & $\begin{array}{l}\text { Valeira } \\
\text { Val }\end{array}$ & $\begin{array}{l}\text { Vilar } \\
\text { VLR }\end{array}$ & $\begin{array}{c}\text { Varosa } \\
\text { VRS }\end{array}$ & $\begin{array}{l}\text { Torrão } \\
\text { TR }\end{array}$ \\
\hline \multicolumn{13}{|l|}{ Environmental variables } \\
\hline $\begin{array}{l}\text { Surface water } \\
\text { temperature }\left({ }^{\circ} \mathrm{C}\right)\end{array}$ & Temp & 15.6 & 16.5 & 16.8 & 13.3 & 14.9 & 16.3 & 15.6 & 12.3 & 15.8 & 16.2 & 19.2 \\
\hline Turbidity (NTU) & Turb & 1.67 & 1.69 & 3.13 & 10.8 & 4.97 & 4.06 & 4.26 & 4.85 & 2.37 & 3.16 & 2.29 \\
\hline $\mathrm{pH}$ (units) & $\mathrm{pH}$ & 8.23 & 7.82 & 7.70 & 7.95 & 8.03 & 8.13 & 7.78 & 7.89 & 7.74 & 7.85 & 7.78 \\
\hline Dissolved oxygen $(\mathrm{mg} / \mathrm{L})$ & DO & 7.98 & 8.29 & 9.30 & 9.20 & 10.8 & 8.61 & 10.3 & 9.53 & 9.57 & 8.88 & 9.29 \\
\hline Hardness $\left(\mathrm{mg} \mathrm{CaCO}_{3} / \mathrm{L}\right)$ & Hard & 168 & 115 & 104 & 181 & 135 & 171 & 127 & 137 & 11.1 & 22.2 & 23.5 \\
\hline Ammonia-N (mg NH $/ / \mathrm{L})$ & $\mathrm{NH}_{4}$ & 0.180 & 0.110 & 0.100 & 0.270 & 0.150 & 0.130 & 0.140 & 0.170 & 0.160 & 0.960 & 0.110 \\
\hline Nitrate- $\mathrm{N}\left(\mathrm{mg} \mathrm{NO}_{3} / \mathrm{L}\right)$ & $\mathrm{NO}_{3}$ & 5.33 & 4.77 & 5.12 & 7.93 & 6.05 & 6.24 & 7.26 & 6.90 & 0.700 & 3.78 & 2.60 \\
\hline Phosphorus $\left(\mathrm{mg} \mathrm{PO}_{/} / \mathrm{L}\right.$ ) & $\mathrm{PO}_{4}^{3}$ & 0.270 & 0.180 & 0.130 & 0.250 & 0.170 & 0.180 & 0.090 & 0.200 & 0.030 & 0.270 & 0.030 \\
\hline Sulfate $\left(\mathrm{mg} \mathrm{SO}_{4} / \mathrm{L}\right)$ & $\mathrm{SO}_{4}$ & 52.7 & 31.9 & 30.4 & 55.4 & 37.9 & 51.1 & 36.3 & 39.2 & 3.29 & 6.74 & 6.45 \\
\hline Cloride $(\mathrm{mg} \mathrm{Cl} / \mathrm{L})$ & $\mathrm{Cl}$ & 19.4 & 13.2 & 12.70 & 17.9 & 14.6 & 17.4 & 12.9 & 15.2 & 5.92 & 11.2 & 7.64 \\
\hline $\begin{array}{l}\text { 5-day Biochemical oxygen } \\
\text { demand }\left(\mathrm{mg} \mathrm{O}^{2} / \mathrm{L}\right)\end{array}$ & BDO & 2.54 & 1.40 & 1.53 & 2.07 & 1.85 & 2.23 & 1.91 & 1.84 & 1.86 & 3.38 & 1.44 \\
\hline Total Silicon $\left(\mathrm{mg} \mathrm{SiO}_{2} / \mathrm{L}\right)$ & $\mathrm{SiO}_{2}$ & 1.26 & 3.14 & 3.57 & 3.15 & 3.29 & 1.69 & 4.34 & 7.28 & 2.02 & 8.41 & 4.94 \\
\hline Total Coliform (N/100 mL) & Tot Colf & 215 & 945 & 1347 & 1449 & 775 & 507 & 1869 & 943.7 & 199 & 2613 & 823 \\
\hline Altitude $(\mathrm{m})$ & Alt & 402 & 71.9 & 13.2 & 528 & 125 & 480 & 73.5 & 105.2 & 552 & 264 & 65.0 \\
\hline Precipitation (mm) & CPREC & 53.4 & 70.2 & 90.4 & 53.9 & 58.9 & 53.4 & 65.0 & 60.5 & 79.4 & 134 & 122.7 \\
\hline Catchment area $\left(\mathrm{km}^{2}\right)$ & A & 63850 & 92050 & 92040 & 63100 & 81005 & 63750 & 90800 & 85400 & 370 & 310 & 3252 \\
\hline Mean dam depth (m) & Depth & 30.8 & 16.7 & 12.9 & 31.9 & 15.6 & 26.9 & 12.1 & 11.5 & 15.7 & 23.5 & 20.7 \\
\hline Time of residence (days) & TimeRes & 9.52 & 5.76 & 2.24 & 1.45 & 2.50 & 3.27 & 2.10 & 3.39 & 320 & & 13.5 \\
\hline Volume $\left(\mathrm{dam}^{3}\right)$ & Vol & 123267 & 141966 & 101563 & 25648 & 94353 & 58946 & 80005 & 92992 & 53567 & 4526 & 91473 \\
\hline Level $(\mathrm{m})$ & LV & 400 & 45.8 & 12.6 & 526 & 107.5 & 469 & 72.9 & 104 & 544 & 245 & 60.2 \\
\hline \multirow{2}{*}{\multicolumn{13}{|c|}{$\begin{array}{l}\text { Biological variables } \\
\text { Phytoplankton ( } n \text { species) }\end{array}$}} \\
\hline & & & & & & & & & & & 170 & \\
\hline $\begin{array}{l}\text { Cyanophyta } \\
\text { Bacillariophyta }\end{array}$ & $\begin{array}{l}\text { CN } \\
\text { DTM }\end{array}$ & $\begin{array}{l}19.0 \\
29.0\end{array}$ & $\begin{array}{l}15.0 \\
28.0\end{array}$ & $\begin{array}{l}16.0 \\
36.0\end{array}$ & $\begin{array}{l}10.0 \\
31.0\end{array}$ & $\begin{array}{l}18.0 \\
30.0\end{array}$ & $\begin{array}{l}18.0 \\
30.0\end{array}$ & $\begin{array}{l}8.00 \\
30.0\end{array}$ & $\begin{array}{l}8.00 \\
26.0\end{array}$ & 22.0 & 18.0 & 24.0 \\
\hline Chlorophyta & CLP & 37.0 & 30.0 & 41.0 & 31.0 & 31.0 & 33.0 & 30.0 & 30.0 & 22.0 & 34.0 & 40.0 \\
\hline Chlorophyll a (mg/L) & Cpl_a & 0.890 & 0.610 & 0.690 & 0.850 & 0.760 & 0.990 & 0.810 & 0.770 & 1.06 & 1.11 & 0.77 \\
\hline \multicolumn{13}{|l|}{ Soil use } \\
\hline Artificial territories (ha) & ART TERT & 111 & 1524 & 778 & 33.5 & 2381 & 208 & 1292 & 1332 & 141 & 328 & 3855 \\
\hline Irrigated crops (ha) & ICROPS & 1786 & 2412 & 4476 & 607 & 32454 & 3107 & 34812 & 61767 & 3489 & 1961 & 22698 \\
\hline Non-irrigated crops (ha) & NICROPS & 0.00 & 1508 & 540 & 0.00 & 84.7 & 0.000 & 167 & 286 & 0.000 & 259 & 2026 \\
\hline $\begin{array}{l}\text { Vineyard (ha) } \\
\text { (hata) }\end{array}$ & VIN & 2779 & 16056 & 0.00 & 27.6 & 20136 & 353 & 38908 & 12596 & 614 & 2258 & 3845 \\
\hline Orchards (ha) & OCHD & 0.000 & 242 & 0.00 & 0.00 & 16111 & 0.000 & 8204 & 7427 & 405 & 2139 & 124 \\
\hline Olive grove (ha) & OLV & 81.6 & 171 & 0.00 & 0.00 & 6613 & 0.000 & 22027 & 18314 & 0.000 & 0.000 & 219 \\
\hline Grasslands (ha) & GRS & 0.800 & 578 & 862 & 0.00 & 2784 & 197 & 2163 & 1379 & 0.000 & 1099 & 4431 \\
\hline $\begin{array}{l}\text { Heterogeneity } \\
\text { agricultural areas (ha) }\end{array}$ & HTAG & 1741 & 25264 & 26510 & 2543 & 93437 & 11547 & 123945 & 118579 & 6893 & 7203 & 73356 \\
\hline Forest (ha) & FRT & 1607 & 17110 & 46514 & 449 & 28559 & 1147 & 53713 & 34339 & 9145 & 3045 & 73462 \\
\hline Shrubs (ha) & SRB & 1451 & 32365 & 36099 & 1048 & 158413 & 1706 & 135861 & 120535 & 6517 & 11527 & 99009 \\
\hline Unproductive areas (ha) & UNPRD & 0.000 & 5915 & 5601 & 0.000 & 1843 & 0.000 & 10548 & 3457 & 5499 & 830 & 10988 \\
\hline Burned areas (ha) & BRN & 84.1 & 0.000 & 2621 & 0.000 & 11944 & 58.8 & 760 & 1521 & 1780 & 0.000 & 153 \\
\hline Interior waters (ha) & RIVERS & 236 & 1027 & 1106 & 57.2 & 1659 & 117 & 966 & 1340 & 475 & 32.2 & 729 \\
\hline $\begin{array}{l}\text { Reservoir type } \\
\text { Sampling periodicity }\end{array}$ & & $\begin{array}{l}\text { "Run-of river" } \\
\text { Trianual }\end{array}$ & $\begin{array}{l}\text { "Run-of river" } \\
\text { Trianual }\end{array}$ & $\begin{array}{l}\text { "Run-of river" } \\
\text { Annual }\end{array}$ & $\begin{array}{l}\text { "Run-of river" } \\
\text { Biannual }\end{array}$ & $\begin{array}{l}\text { "Run-of river" } \\
\text { Biannual }\end{array}$ & $\begin{array}{l}\text { "run-of river" } \\
\text { Annual }\end{array}$ & $\begin{array}{l}\text { "Run-of river" } \\
\text { Trianual }\end{array}$ & $\begin{array}{l}\text { "Run-of river" } \\
\text { Trianual }\end{array}$ & $\begin{array}{l}\text { Reservoir } \\
\text { Annual }\end{array}$ & $\begin{array}{l}\text { Reservoir } \\
\text { Annual }\end{array}$ & $\begin{array}{l}\text { Reservoir } \\
\text { Annual }\end{array}$ \\
\hline
\end{tabular}


the year mostly related to the seasonality of the inputs of water. The main characteristics of the studied reservoirs are presented in Table 1.

\subsection{Environmental variables and chlorophyll a}

The environmental and biological variables were measured by the national Laboratory of Environment and Applied Chemistry (LABLEC), from 1996 to 2004, four times per year, corresponding to spring, summer, autumn and winter. These variables were sampled according to the methodologies described by CEN/TC 230. All samples were collected at $100 \mathrm{~m}$ from the reservoirs's crest, at approximately $0.5 \mathrm{~m}$ depth. From all reservoirs, 58.8\% were sampled annually, $26.5 \%$ biannually and $14.7 \%$ triennially (Table 1 ).

To determined soil use dynamics in Douro watershed, i.e., rates of soil use alterations, a geographic information system database was created (ESRI, ArcGIS 9.0), with 13 spatial variables (see Table 1). These use/land cover variables derived primarily from the Corine Land Cover from two distinct decades 1990 and 2000 (CLC, 1990 and 2000; IGEOE, 2006), additionally the proportions of the predominant CLC classes in the basin (urban areas, intensive and extensive agriculture, natural and semi-natural areas and burned areas) were calculated.

The trophic classification of reservoirs was obtained from the OCDE model (Vollenweider and Kerekes, 1982), based on Total Phosphorus, Shecchi Depth and Mean Chlorophyll a concentration (see Table 1).

\subsection{Biological variables}

The phytoplankton samples were collected from 1996 to 2004, with the periodicity described for the environmental parameters, using a Van Dorn bottle net, at a depth of approximately $0.5 \mathrm{~m}$. Phytoplankton community composition was studied through inverted microscopy, following Utermohl's method (Lund et al., 1958). For the quantification and identification of phytoplankton, samples were fixed in Lugol's solution $(1 \%, \mathrm{v} / \mathrm{v})$ and, when possible, identified to the species level. The abundance of each taxon was estimated using a 5 -score scale criteria (0-absent to 4-bloom).

\subsection{Statistical analysis and modelling procedures}

The soil use dataset, the base of the dynamic sub-model of our StDM application (level 1), incorporates real gradients relying on land cover alterations through one decade, from 1990s to 2000s, in the Douro river watershed.

A stepwise multiple-regression analysis (Zar, 1996) was used to test relationships between the soil use dynamics within the watershed (level 1) and the physicochemical variables of the reservoir (level 2) and between these aquatic environmental variables and the phytoplankton metrics (level 3). In level 2, the dependent variables, selected as representative of the physicochemical status of water column reservoir, were: total coliforms, $\mathrm{PO}_{4}, \mathrm{Cl}, \mathrm{NH}_{4}, \mathrm{BOD}_{5}, \mathrm{pH}, \mathrm{SiO}_{2}, \mathrm{DO}, \mathrm{NO}_{3}$, hardness, turbidity and $\mathrm{SO}_{4}$. For this level, the independent variables considered were the 13 soil use variables and the 5 stochastic environmental variables, namely surface water temperature, precipitation, volume, level and water residence time (see Table 1 for details).

In level 3, the dependent variables, selected as representative of the local phytoplankton, were: Cyanophyta (Blue-green algae), Clorophyta (Green algae), Bacillariophyta (diatoms) and Chlorophyll $a$. The independent variables considered for the phytoplankton metrics were the 17 environmental variables referred above for level 2 and for the stochastic environmental variables.

From a bottom up perspective, each living component interacts with other living components and non-living features of their shared habitat. A step down procedure was used to test the effect of each variable in the presence of all other pertinent variables, with the least significant variable being removed at every step. The analysis stopped when all the remaining variables had a significant level $P<0.05$ (Zar, 1996). The multi-level approach gives realism to the interactions considered by incorporating into the model a typical "cascade effect" observed in these processes (Brazner et al., 2007; Bailey et al., 2007). Therefore, in order to simplify the model structure, only the main key-components were introduced as representative ecological indicators, but which obviously could be complemented by other relevant state variables or other dynamic variables in further applications. The specifications of all variables considered are indicated in Table 1. Although the lack of normality distribution of the dependent variables was not solved by any transformation (Kolmogorov-Smirnov test), the linearity and the homoscedasticity of the residuals were achieved by using logarithmic transformations $\left(X^{\prime}=\log [X+1]\right)$ in each side of the equation, i.e., on both the dependent and independent variables (Zar, 1996; Podani, 2000). The lack of substantial intercorrelation among independent variables was confirmed by the inspection of the respective tolerance values. All the statistical analysis was carried out using the software SYSTAT $8.0^{\circledR}$.

Since this statistical procedure was based on a very complete database, covering true gradients of environmental and biological characteristics of the reservoirs in the Douro basin (Fig. 1), over space and time, the significant partial regression coefficients were assumed as relevant holistic ecological parameters in the dynamic model construction. This is the heart of the philosophy of the StDM. In a holistic perspective, the partial regression coefficients represent the global influence of the environmental variables selected, which are of significant importance on several complex ecological processes. To develop the dynamic model the software STELLA 8.1.4 ${ }^{\circledR}$ was used.

Water quality indices and trophic level classification system are useful tools for enhancing communications between scientists, water managers, policymakers and/or the general public. Therefore, some of the ecological indicators selected were described using Carlson's Trophic Status Index (TSI). The status for Secchi depth (SD), chlorophyll $a$ (Clp a) and total phosphorus (TP) were described using the following equations (Carlson, 1977):

$\mathrm{TSI}(\mathrm{SD})=60-14.41 \times \ln \mathrm{SD}(\mathrm{m})$;

TSI $($ Clp_a $)=9.81 \times \ln$ Clp_a $(\mu g / \mathrm{L})+30.6$;

$\mathrm{TSI}(\mathrm{TP})=14.42 \times \ln \mathrm{TP}(\mu \mathrm{g} / \mathrm{L})+4.15$ 
Other indices have been constructed to be used as a complement of these basic three. Since nitrogen limitation still classifies a lake along Naumann's nutrient axis, the effect of nitrogen limitation can be estimated by having a companion index to the TSI(TP). Therefore, the TSI(TN) was introduced in the model and calculated using the following formula (Kratzer et al., 1982):

\section{$\mathrm{TSI}(\mathrm{TN})=54.45+14.43 \times \ln \mathrm{TN}(\mathrm{mg} / \mathrm{L})$.}

A major strength of TSI is that the interrelationships between variables can be used to identify certain conditions in the lake or reservoir that are related to the factors that limit algal biomass or affect the measured variables. The concept of trophic status is based on the fact that changes in nutrient levels (measured by TP and NT) causes changes in algal biomass (estimated by Clp_a measures) which in turn causes changes in lake clarity (measured by SD). TSI values greater than 50 are associated with eutrophy (high productivity). The range between 40 and 50 is usually associated with mesotrophy (moderate productivity) and values less than 40 are associated with oligotrophy (low productivity) (Carlson, 1981, 1983). Since some of these trophic variables do not survive when the initial stepwise multi-regression analysis was carried out, namely TP and SD, significant relationships were found between them and other environmental variables from the StDM model. Therefore, simple linear regression models were introduced in the model in way to estimate the concentration of total phosphorus from total nitrogen concentration (TN, as a sum of $\mathrm{NO}_{3}$ and $\left.\mathrm{NH}_{4}\right)(y=0.018 x+0.023$; $\left.R^{2}=0.348 ; N=25\right)$ and Secchi disk transparency from turbidity $\left(y=0.775 x+3.83 ; R^{2}=0.732 ; N=25\right)$.

For validation purposes, a set of biological and environmental data (including land cover) from the Torrão reservoir, that are independent of the data used to structure the StDM model and estimate its parameters, were used to confront the simulated values of a given state variable with the real values of the same component. A regression analysis (MODEL II) was performed to compare the observed real values of the selected variables with the expected values obtained by model simulations for the same periods. At the end of each analysis, the $95 \%$ confidence limits for the intercept and the slope of the regression line were determined which, together with the results of the respective analysis of variance (ANOVA), allowed to assess the proximity of the simulations produced with the observed values (Sokal and Rohlf, 1995). When the results of the regression analysis were statistically significant, i.e., when the intercept of the regression line was not statistically different from 0 and the slope was not statistically different from 1, the model simulations were considered validated (Sokal and Rohlf, 1995; Oberdorf et al., 2001).

The model is prepared to work with table functions for validation purposes (Validation Mode) and to produce stochastic simulations based on the monthly stochastic variability of some environmental variables (Random Mode). Simulations based on stochastic principles take into consideration the random behaviour of some environmental variables with influence on the studied ecological phenomena. The limit values of environmental variables were determined, from the period between December 1995 and December 2004, to discriminate the maximum and minimum values of each stochastic environmental variable, included in the model as a RANDOM function (Annex 1, Other functions). The selection of the model working mode is done by switching the toggle option between 0 and 1 for validation or stochastic calculations, respectively. The Annex 1 is available in the online version of this article as Electronic Supplementary Material.

\section{Results and discussion}

\subsection{Multi-level interactions}

In the StDM, a stepwise multiple-regression analysis was used to search for significant correlations between the different levels of variables used in the model construction. In level 2, the physicochemical variables were influenced by several types of soil use and stochastic environmental variables, such as the cumulative precipitation (CPREC) and water temperature.

The upper level (level 3), represented by the number species of Cyanophyta (CN), Clorophyta (CPL), Bacillariophyta (DTM) and Chlorophyll $a$ (Clp_a) concentration was influenced by the preceding levels, particularly by environmental variables, including the stochastic ones (Table 2). Several studies, all over the world, have demonstrated that these environmental variables played an important role in structuring phytoplankton assemblages, namely nutrient concentrations, water mineral content, $\mathrm{pH}$, temperature, dissolved oxygen and silicon (EPA, 1998; Dokulil and Teubner, 2000; Wetzel, 2001; Figueiredo et al., 2006; McIntire et al., 2007). The influence of nitrogen $\left(\mathrm{NH}_{4}\right.$ and $\left.\mathrm{NO}_{3}\right)$ concentration either negative on species richness of $\mathrm{CN}$ and $\mathrm{CPL}$ or positive on species richness of DTM corroborates other studies in worldwide reservoirs that have come to similar results (e.g., Figueiredo et al., 2006; McIntire et al., 2007). Moreover, the inorganic nitrogen hypothesis suggests that the forms and amounts of inorganic nitrogen favor different algal groups. Non-N-fixing Cyanobacteria are favored by ammonium-nitrogen, while eukaryotic phytoplankton develops when nitrate-nitrogen is the main $\mathrm{N}$ component present (Dokulil and Teubner, 2000; Figueiredo et al., 2006). Scarcity of nitrogen induces nitrogen-fixation and hence favors the development of species capable to fix molecular nitrogen (Blomqvist et al., 1994; Dokulil and Teubner, 2000). This could explain the apparent contradictory results obtained for the influences of $\mathrm{NH}_{4}$ in dry or wet years for this algal group (Table 2). Some authors have demonstrated that diatoms were positively correlated with trophic gradients, high TN/TP-ratios, water mineral content and hardness (Negro and De Hoyos, 2005).

All these hypotheses largely corroborate the obtained results, as shown in Table 2.

\subsection{Conceptualization of the model and equations}

The conceptual diagram of the model shown in Fig. 2 is based on the perceived dynamic relationships between different soil uses present in the Douro watershed (level 1), expressed by the trends of the land cover recorded through a decade, from 1990 to 2000. In this level, the model included eleven state variables related to land cover: Artificial Territories (ART TERT), 
Table 2 - The regression equations, coefficient of determination $\left(R^{2}\right)$, F-values and their significance level $(" \mathrm{P}<0.001)$ for all the variables combination selected as significant by stepwise multiple regression

Equations

$\mathrm{D}$ or $\mathrm{W}$

Months

Environmental variables

(20)

188

$\log$ Tot Colf $=179.521+17.392(\log$ ALT $)+7.673(\log$ A $)+46.375(\log$ CPREC $)+2.301(\log$ ART_TERT $)+3.453(\log$ SRB $)+$

1.128 (log UNPRD + 0.263 (log_BRN) - 17.572 (log Deep) - 2.809 (log_NICROPS) - 1.154 (log OCHD) - 2.420 (log_HTAG)

$\log \mathrm{Cl}=6.622+0.175(\log$ TIMERS $)+0.048\left(\log \_\right.$VIN $)+0.209(\log$ OCHD $)+0.461\left(\log \_H T A G\right)+0.201\left(\log\right.$ INT_WT) $-1.313\left(\log \_N V\right)-$

$0.223(\log A)-0.603(\log$ ART_TERT) - 0.169 (log_SRB) -0.438 (log_UNPRD) - 0.035 (log_BRN)

$\log \mathrm{SO}_{4}=7.509+0.154(\log \mathrm{OCHD})+0.184\left(\log \_\mathrm{HTAG}\right)-0.961$ (log_NV) - $1.635\left(\log \_\mathrm{CPREC}\right)-0.174(\log$ ART_TERT $)-$

0.229 (log_SRB) $-0.258(\log$ UNPRD)

$\log$ BDO $=-131.535+12.974(\log$ ALT $)+5.950(\log A)+27.111(\log$ CPREC $)+0.213(\log$ TIMERS $)+0.918(\log$ GRSL $)+1.632(\log$ _FRT $)+$

$2.186\left(\log \_S R B\right)+1.628(\log$ UNPRD) + $0.228(\log$ INT_WT $)-6.825(\log$ Deep) $-0.393(\log$ ART_TERT) -0.743 (log OCHD) -

0.367 (log_OLV) -4.468 (log_HTAG)

$\log \mathrm{PO}_{4}=-14.403+1.560(\log$ ALT $)+0.636(\log \mathrm{A})+3.672\left(\log \_\right.$CPREC $)+0.058(\log$ TIMERS $)+0.087\left(\log \_\right.$GRSL $)+0.267\left(\log \_\right.$FRT $)+$

$0.427\left(\log \_S R B\right)+0.014\left(\log \_B R N\right)-0.083(\log$ TEMP) $-1.783(\log$ Deep) $-0.353(\log$ _NICROPS) $-0.092(\log$ OCHD) -0.367 (log_HTAG)

$\log \mathrm{NH}_{4}=33.068+0.290\left(\log \_\mathrm{OLV}\right)+1.400\left(\log \_\right.$HTAG $)-2.335\left(\log \_N V\right)-0.106(\log \mathrm{Vol})-1.88(\log$ Deep $)-1.56(\log \mathrm{A})-$

4.65 (log_CPREC) - 0.11 (log ART_TERT) - 1.03 (log_NICROPS) -0.15 (log_GRS) - 0.79 (log_UNPR)

$\log \mathrm{SIO}_{2}=-25.685+1.103(\log \mathrm{A})+7.255(\log$ CPREC$)+0.477\left(\log\right.$ ART_TERT) $+0.575($ NICROPS $)+0.352(\log$ OCHD $)+0.674\left(\log \_N V\right)-$

0.477 (log TEMP) - 0.205 (log OLV) -0.282 (log GRSL) - 0.646 (log_SRB)

$\log \mathrm{NO}_{3}=9.459+0.147\left(\log \_\right.$OLV $)+0.630\left(\log \_\right.$HTAG $)+0.273(\log$ INT_WT $)-0.927(\log$ TEMP $)-1.234(\log$ ALT $)-0.382(\log$ A) -

$0.372(\log$ ART_TERT $)+0.782\left(\log \_\right.$FRT $)+0.209\left(\log \_\right.$UNPRD $)$

$\log \mathrm{pH}=-8.813+0.094(\log \mathrm{TEMP})+0.031(\log \mathrm{Vol})+0.450(\log \mathrm{A})+1.786\left(\log \_\mathrm{CPREC}\right)+0.037(\log$ TIMERS $)+$

0.174 (log_NICROPS) + $0.053\left(\right.$ log_GRSL) + $0.135\left(\log \_S R B\right)+0.136\left(\log \_\right.$UNPRD $)+0.726\left(\log \_N V\right)-0.065$ (log_OLV) $-0.390\left(\log \_H T A G\right)$

$\log \mathrm{DO}=-44.268+3.409(\log$ Deep $)+2.231(\log \mathrm{A})+5.803(\log$ _CPREC $)+1.670($ NICROPS $)+0.271(\log$ _GRSL $)+1.251(\log$ _UNPRD $)+$

$3.230\left(\log \_\right.$NV) $-0.148(\log$ TEMP) -0.431 (log_OLV) -2.167 (log_HTAG)

$\log$ Turb $=1.750+0.126($ log_NICROPS) -0.448 (log TEMP) -0.405 (log Deep) -0.100 (log TIMERS) - 0.194 (log ART_TERT)

$\log$ Hard $=7.196+2.190(\log$ ALT $)+0.157\left(\log \_\right.$OLV $)+0.454\left(\log \_\right.$HTAG $)-2.341(\log$ Deep $)-0.199(\log$ ART_TERT $)-$

0.288

$6.459^{\cdots+\cdots}$

0.531 (log_NICROPS) -0.407 (log_UNPRD) - 2.613 (log_NV)

Biological variables

$\log \mathrm{Clp} \_a=0.747+0.801(\log \mathrm{Cl})+0.158\left(\log \mathrm{CBO}_{5}\right)-0.029(\log$ TotColf $)+0.351\left(\log \mathrm{SO}_{4}\right)-0.163(\log$ Deep $)-$

$0.363\left(\log _{-}\right.$CPREC $)-0.521\left(\log \mathrm{PO}_{4}\right)$

$\log \mathrm{Clp} \_a=0.552+0.731(\log \mathrm{pH})-0.389(\log \mathrm{DO})-1.040\left(\log \mathrm{PO}_{4}\right)-0.113(\log \mathrm{Vol})$

$\log \mathrm{CLP}=-4.790+0.268(\log$ ALT $)+0.280(\log \mathrm{A})+1.264\left(\log \_\mathrm{CPREC}\right)-0.228\left(\log \mathrm{NO}_{3}\right)$

$\log$ CLP $=0.406+0.885(\log$ HARD $)+2.119\left(\log \mathrm{PO}_{4}\right)-0.791\left(\log \mathrm{NH}_{4}\right)-0.915\left(\log \mathrm{SO}_{4}\right)$

$\log$ DTM $=-2.165+0.301\left(\log \mathrm{NO}_{3}\right)+0.217(\log \mathrm{A})+0.713(\log \mathrm{CPREC})+0.162(\log \mathrm{TIMERS})-0.245\left(\log \mathrm{SiO}_{2}\right)+0.155(\log \mathrm{Vol})$

$\log$ DTM $=-5.099+0.961(\log \mathrm{HARD})+0.468\left(\log \mathrm{NH}_{4}\right)+0.502\left(\log \mathrm{CBO}_{5}\right)+0.537(\log \mathrm{Vol})+0.384(\log \mathrm{ALT})+1.619(\log \mathrm{CPREC})$

$1.423(\log \mathrm{Cl})-0.746(\log$ Deep)

$\log \mathrm{CN}=1.060+1.380(\operatorname{log~NH} 4)-0.577(\log \mathrm{Cl})-0.290\left(\log \mathrm{SiO}_{2}\right)$

$\log \mathrm{CN}=-0.045+0.275(\log$ TURB $)+1.477\left(\log \mathrm{PO}_{4}\right)+0.925(\log \mathrm{Deep})+0.225(\log$ TIMERS $)-0.472(\log \mathrm{DO})-0.530\left(\log \mathrm{NH}_{4}\right)-$

188

188

188

0.731

$43.427^{\cdots+\cdots}$

0.896

$221.622^{+* *}$

188

0.247

$4.051^{\cdots+\cdots}$

$188 \quad 0.406$

$9.153^{\cdots+\cdots}$

$188 \quad 0.362$

$9.088^{* \cdots+}$

$188 \quad 0.474$

$15.969^{*+*}$

$188 \quad 0.728$

$52.912^{*+*}$

188

0.252

$4.921^{\cdots+\cdots}$

188

0.156

$3.274^{\cdots+\cdots}$

188

$0.325\left(\log \mathrm{NO}_{3}\right)-0.210(\log$ ALT $)$

For biological variables the dry (D) and wet (W) months were discriminated. The specification of all variable codes is expressed in Table 1. 


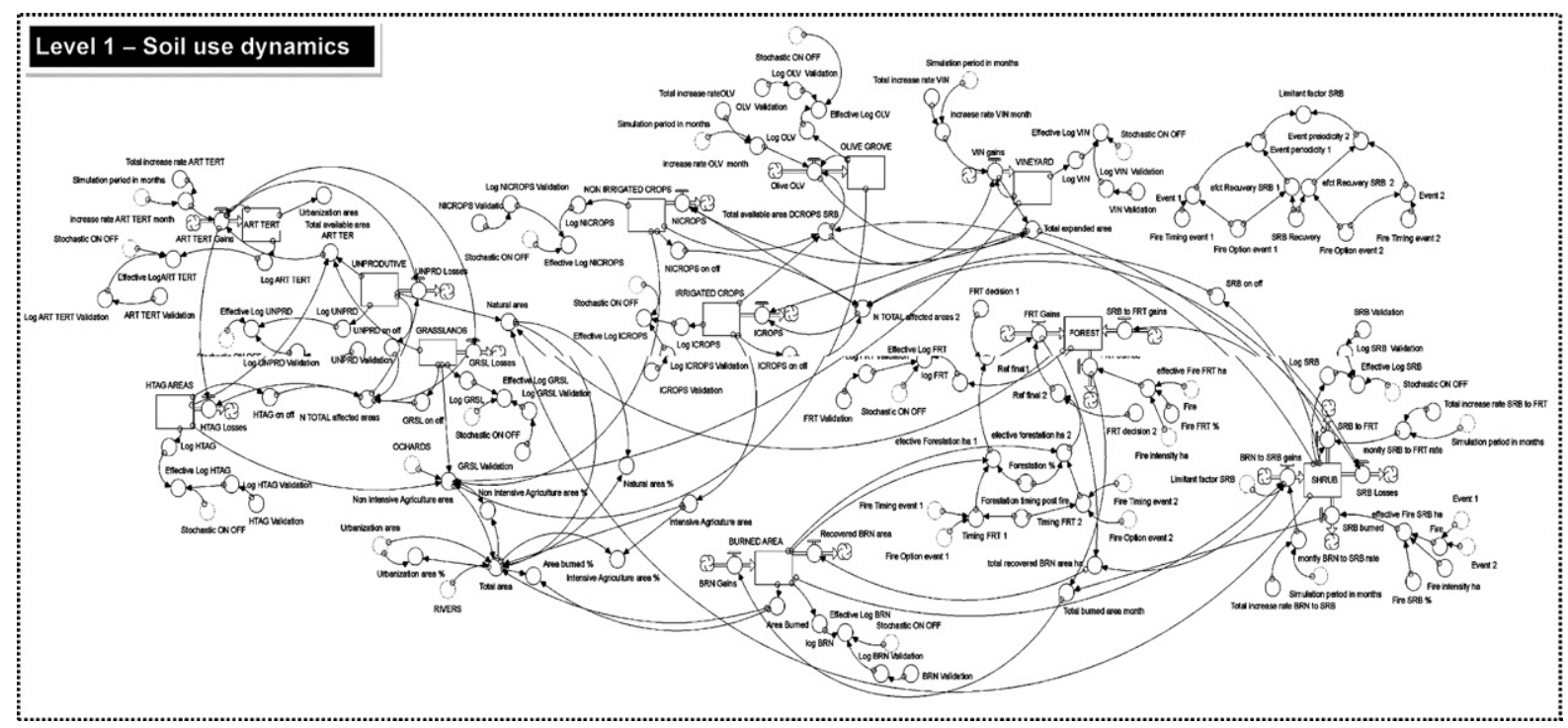

Fig. 2 - Conceptual diagram of the sub-model used to predict the soil use dynamics, representing the level 1 in the global StDM model, the base for assessing the ecological status of the reservoirs in the Douro watershed. The specification of all variable codes is expressed in Table 1.

Unproductive areas (UNP), Grasslands (GRS), Heterogeneity agricultural areas (HTAG), Irrigated crops (ICROPS), Nonirrigated crops (NICROPS), Olive grove (OLV), Vineyard (VIN), Forest (FRT), Burned areas (BRN) and Shrubs (SRB). Difference equations describing the processes affecting these state variables are expressed in area units (hectares) (Annex 1, State variable equations). As initial values of all state variables, indicated in Annex 1 (Process equations), were considered data recorded in Torrão's Watershed between December 1995 and December 2004.

The increase rates used for artificial territory, olive grove, vineyard and shrubby vegetation were calculated according to the ratio ((soil use area in 2000 - soil use area in 1990)/soil use area in 1990)) (Chaves et al., 2000). Since the time unit chosen was the month, because it captures in an acceptable way the behaviour of the variables at the lower scales of our proposed approach (levels 2 and 3), the increase rates (Total increase rate ART TERT, Total increase rate OLV, Total increase rate VIN, Total increase rate BRN to SRB and Total increase rate SRB to FRT) were converted to monthly periods (increase rate ART TERT month, increase rate OLV month, increase rate VIN, increase rate BRN to SRB month and increase rate SRB to FRT month) by using the appropriated rate conversions described in Annex 1 (Composed variables). The simulation period for a decade was expressed in months, i.e., 120 months (see Annex 1 , constants).

In each time unit, the available area for each type of expansible soil use (Total available area ART TERT, Total available area DCROPS_SRB, Total available area OLV_VIN) (Annex 1, Composed variables) was calculated by the sum of all the pertinent soil use areas which were expected to be occupied by these activities ( $\mathrm{N}$ Total affected areas; see Annex 1 , Composed variables). Although this version of the model is now prepared to simulate new scenarios, such as the effect of one or two fires and/or the consequences of a reforestation action in reservoir's water quality, it is not the goal of the present paper to extend the line of post-validation applications, as the subsequent article in preparation by our team follow this goal.

The conceptual diagrams presented in Figs. 3 and 4 reflect the relationships detected in multiple-regression analysis (Table 2) and on existing relevant regional data sets. Therefore, the StDM model includes globally the following 27 state variables: eleven related to the soil use dynamics (level 1), twelve related to physicochemical variables (level 2) and four related to biological metrics (level 3) (Figs. 2-4, respectively). Since difference equations that described the processes affecting the state variables from the levels 2 and 3 were expressed in logarithms, the initial values of these state variables were expressed in logarithms of the original units (Annex 1, State variable equations and Process equations). Later, for validation purposes, the initial value (December 1995) was discarded, since only in t1 (first point of the simulation) it was possible to take into account the influences of the environmental variables, whose seasonal fluctuations were introduced into the model as table functions (Annex 1, Table functions). The selected biological metrics largely depend on weather conditions, namely on precipitation and related variables like water residence time (Reynolds, 1984; Basu and Pick, 1996; EPA, 1998; Dokulil and Teubner, 2000). Therefore, two different complementary equations were calculated for each state variable of phyroplankton groups considered, depending on the monthly precipitation. The categorization in dry or wet months was determined by comparing monthly cumulative precipitations with the reference historical values of monthly precipitation obtained from the period between 1961 and 1990 (Portuguese Weather Institute, 2007). Consequently, the simulation performance of a given state variable results from the calculations of two alternative equations automatically selected in response to 


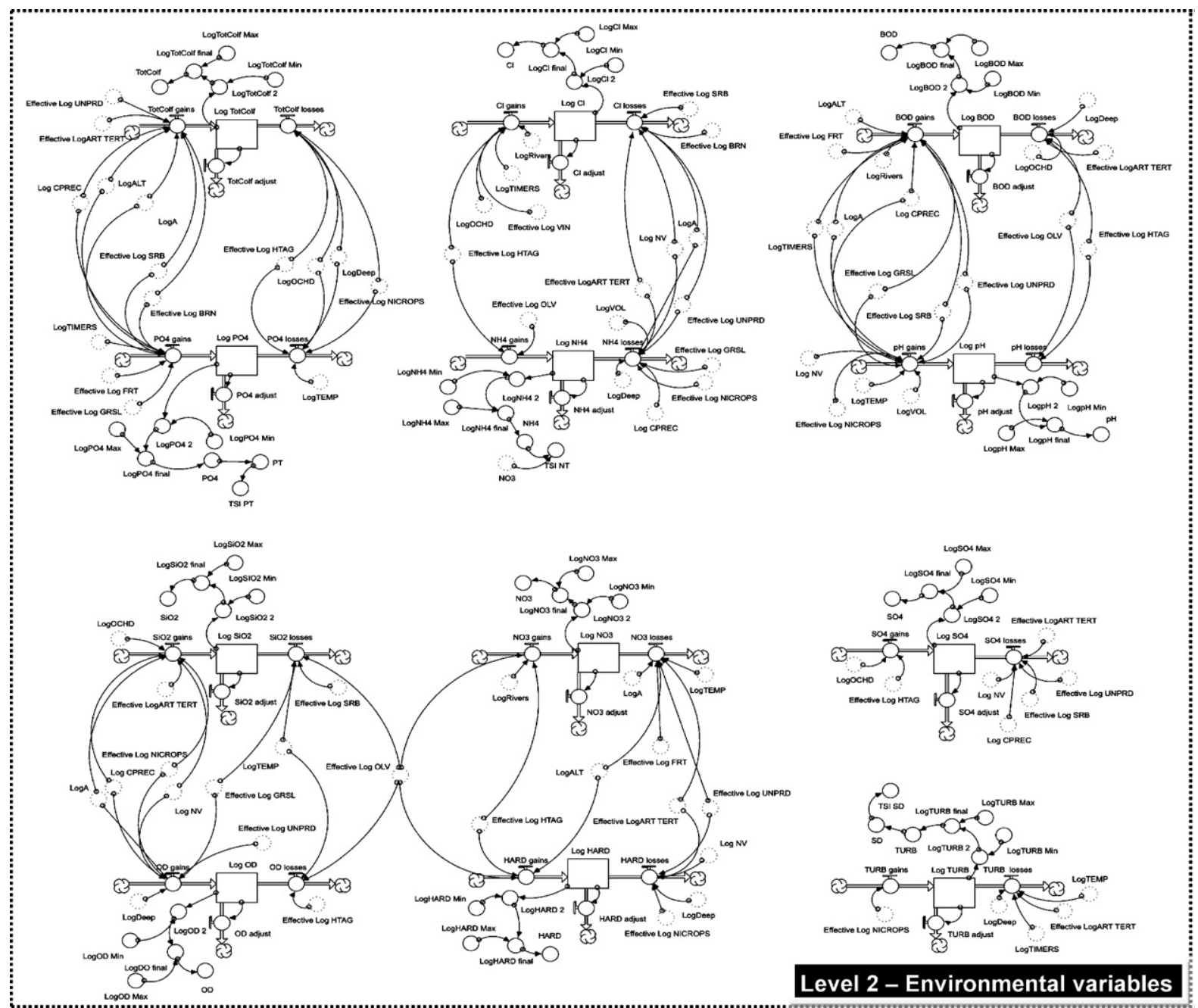

Fig. 3 - Conceptual diagram of the sub-model used to predict the responses of the water column environmental variables to changes due to soil use dynamics, representing the level 2 in the StDM model for the Douro watershed reservoirs. The specification of all variable codes is expressed in Table 1.

the monthly precipitation influence (Fig. 4, Table 2 and Annex 1 , State variable equations). The inflows affecting the state variables, in levels 2 and 3, were based on the positive constants and all positive partial coefficients of each variable resulting from the previous multiple-regression analysis (Figs. 3 and 4, Table 2 and Annex 1, State variable and Process equations). Chlorophyll $a$ and the number of species of Cyanophyta, Bacillariophyta and Chlorophyta were affected by two inflows corresponding to the conditions of dry or wet months (Clp_a gains Dry, Clp_a gains Wet, CLP gains Dry, CLP gains Wet, CN gains Dry, CN gains Wet, DTM gains Dry and DTM gains Wet). Using the same criteria, each one of these state variables was affected by two outflows related to the negative constants and partial regression coefficients (Figs. 3 and 4, Table 2 and Annex 1, State variable and Process equations) (Clp_a losses Dry, Clp_a losses Wet, CLP losses Dry, CLP losses Wet, CN losses Dry, CN losses Wet, DTM losses Dry, DTM losses Wet). To complement the information about the ecological status of reservoir's water quality, the trophic state indices (TSI) based on chlorophyll $a$, total nitrogen, total phosphorus and Secchi disk depth outputs were introduced into the model (Figs. 3 and 4, Annex 1, Composed variables). Although the StDM simulations for each physicochemical or biological metric were composed of a given value per time unit, the respective state variable might had a cumulative behaviour over time in response to environmental condition changes. Therefore, to prevent this from happening, sixteen outflow adjustments were incorporated in the model (Level 2: $\mathrm{BDO}$ adjust, $\mathrm{Cl}$ adjust, $\mathrm{Hard}$ adjust, $\mathrm{NH}_{4}$ adjust, $\mathrm{NO}_{3}$ adjust, $\mathrm{DO}$ adjust, $\mathrm{pH}$ adjust, $\mathrm{PO}_{4}$ adjust, $\mathrm{SiO}_{2}$ adjust, $\mathrm{SO}_{4}$ adjust, TotColf adjust, Turb adjust; Level 3: Clp_a adjust, CLP adjust, CN adjust, and DTM adjust) aiming to empty the state variables at each time step, by a "flushing cistern mechanism", before beginning the next step with new environmental influences (Figs. 2 and 3, Annex 1, State variable and Process equations). For process compatibilities and a more realistic comprehension of the model simulations, some conversions were introduced, denominated associated variables (Figs. 2-4 and Annex 1, Associated variables). Regarding biological and physicochemical variables, these conversions were obtained through an inverse transformation (anti-logarithmic), which transforms logarithms into the original measurement units 
Level 3 - Bioloqical variables

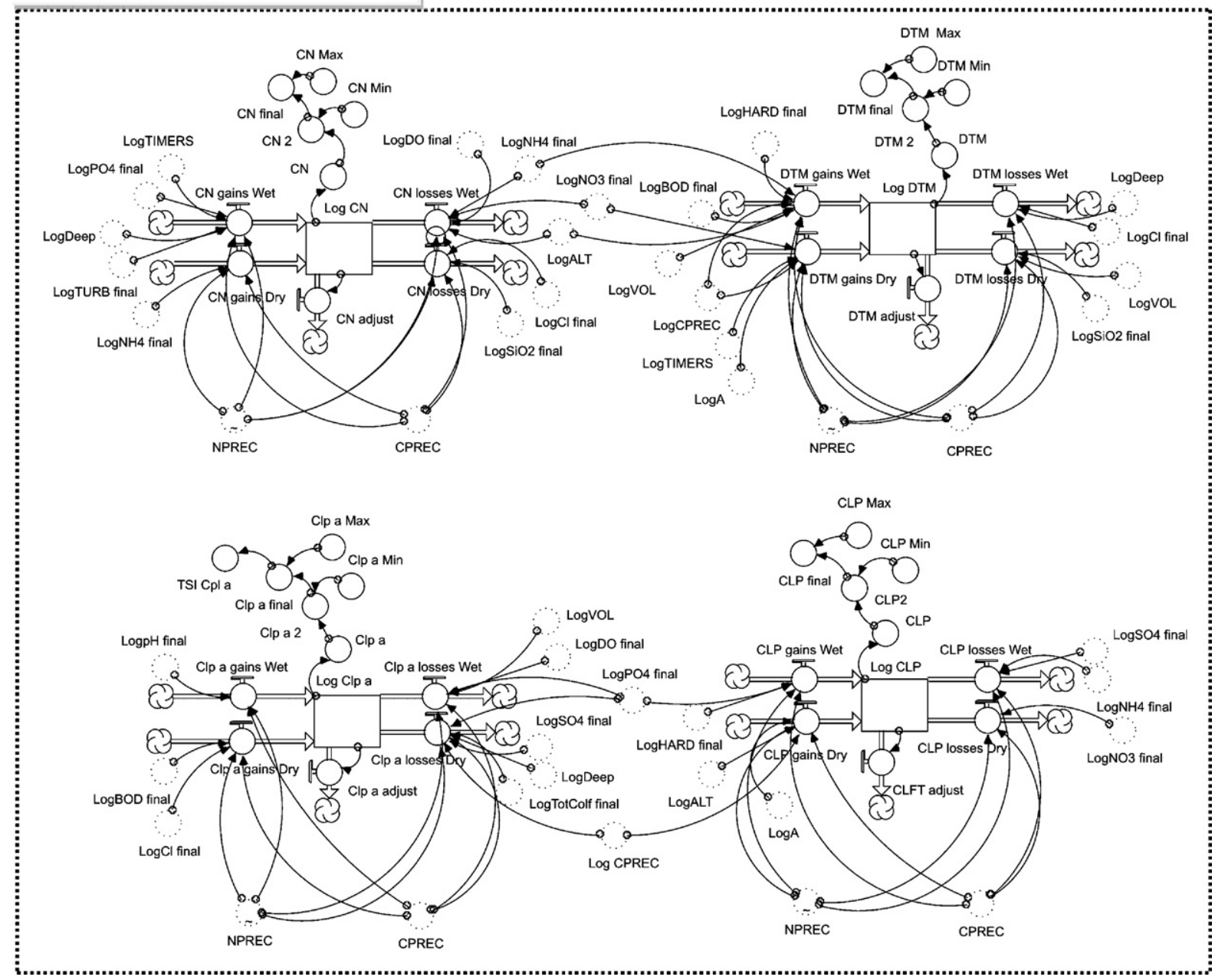

Fig. 4 - Conceptual diagram of the sub-model used to predict the responses of biological variables to changes in the water column environmental variables, representing level 3 in the StDM model for the Douro watershed reservoirs. The specification of all variable codes is expressed in Table 1.

(Level 2: BDO, Cl, Hard, $\mathrm{NH}_{4}, \mathrm{NO}_{3}, \mathrm{DO}, \mathrm{pH}, \mathrm{PO}_{4}, \mathrm{SiO}_{2}, \mathrm{SO}_{4}$, TotColf, Turb; Level 3: Clp_a, CLP, CN, and DTM). The output of the level 1 (soil uses) were logarithm transformed for a compatible integration in the balances of the state variables from the levels 2 and 3 (Figs. 2 and 3, Annex 1, Associated variables). This transformation was incorporated because the data required for the state variables balances in levels 2 and 3 should have the same units used to obtain the partial regression coefficients, assumed as holistic ecological parameters (see Section 2). Therefore, only logarithms of the soil uses are acceptable in the inflows and outflows of these state variables (Figs. 2 and 3, Table 2 and Annex 1, State variable and Process equations). Thus, the StDM model is prepared for receiving and transforming real data from the variables in level 1 and to convert logarithmic outputs from state variables simulations into original units in levels 2 and 3. Some environmental values, were assumed as static in each reservoir, without any variation during the simulated period, and, therefore, were introduced as environmental constants (Annex 1, Constants). The stochastic behaviour of some environmental variables were determined by RANDOM functions, with a monthly variation, taking into account the standard deviations limits for each environmental variable considered (Fig. 5 and Annex 1, Other functions).

\subsection{Model simulations}

Simulations were performed from December 1995 to December 2004. Since the values of the first month for each period were used as initial values (t0), the simulations started effectively in January 1996. The Figs. 6 and 7 illustrate the confrontation between simulated and real values for main relevant physicochemical and biological variables under consideration. The model predicted with success fourteen of the twenty-two simulations performed. In fact, the behaviour of some variables namely: physicochemical variables (Cl, DO, Hard, pH, PT, SD and Turb), biological variables (CLP, CN and DTM) and trophic state indices (TSI Clp_a, TSI NT, TSI PT and TSI SD) (Figs. 6 and 7, respectively) were statistically 


\section{Stochastic environmental variables}

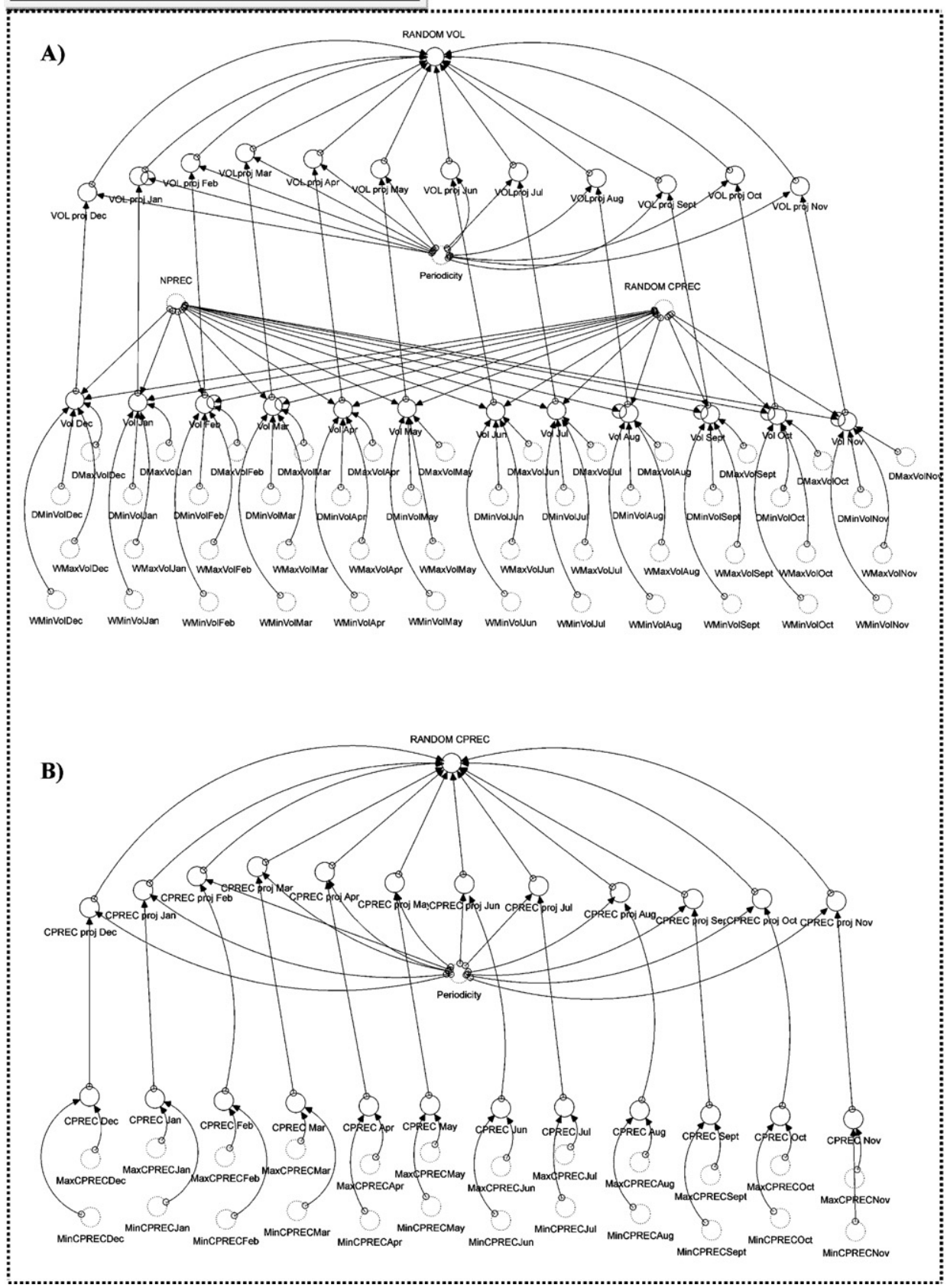

Fig. 5 - Conceptual diagrams of the sub-model used to generate monthly stochastic calculations from the environmental data incorporated into the model: (A) standard diagram used for physical stochastic variables, and (B) standard diagram used for monthly meteorological stochastic simulations. For illustration purposes, the diagrams for the volume of the reservoir (VOL) and cumulative precipitation (CPREC) are shown as respective examples.

validated by the MODEL II regression analysis (Table 3). Despite the non-significant results for the remaining simulations, it was easily recognized a logic behavioural pattern for $\mathrm{NO}_{3}$ and Clp_a (Figs. 6 and 7, respectively; Table 3) consistent with the observed parameters at the Torrão's reservoir for the same real conditions. Moreover, some of the non-validated variables, namely Clp_a, $\mathrm{PO}_{4}, \mathrm{NH}_{4}$ and $\mathrm{NO}_{3}$ (Table 3), when expressed in the respective four metrics based on Carlson's Trophic Status Index criteria, were able to capture, with a notable performance, the expected behaviour of these transformed metrics (Table 3 and Fig. 7).

A relative stable seasonal pattern of phytoplankton succession and biomass variations were observed for all the biological variables analysed (Figs. 6 and 7). These patterns were consistent with the behaviour of these groups facing similar contexts of other temperate lakes and reservoirs (Reynolds, 1984; Oliveira, 1987; Mischke, 2003; Figueiredo et al., 2006). These seasonal successions are strongly conditionated 


\section{Level 2 - Environmental variables}
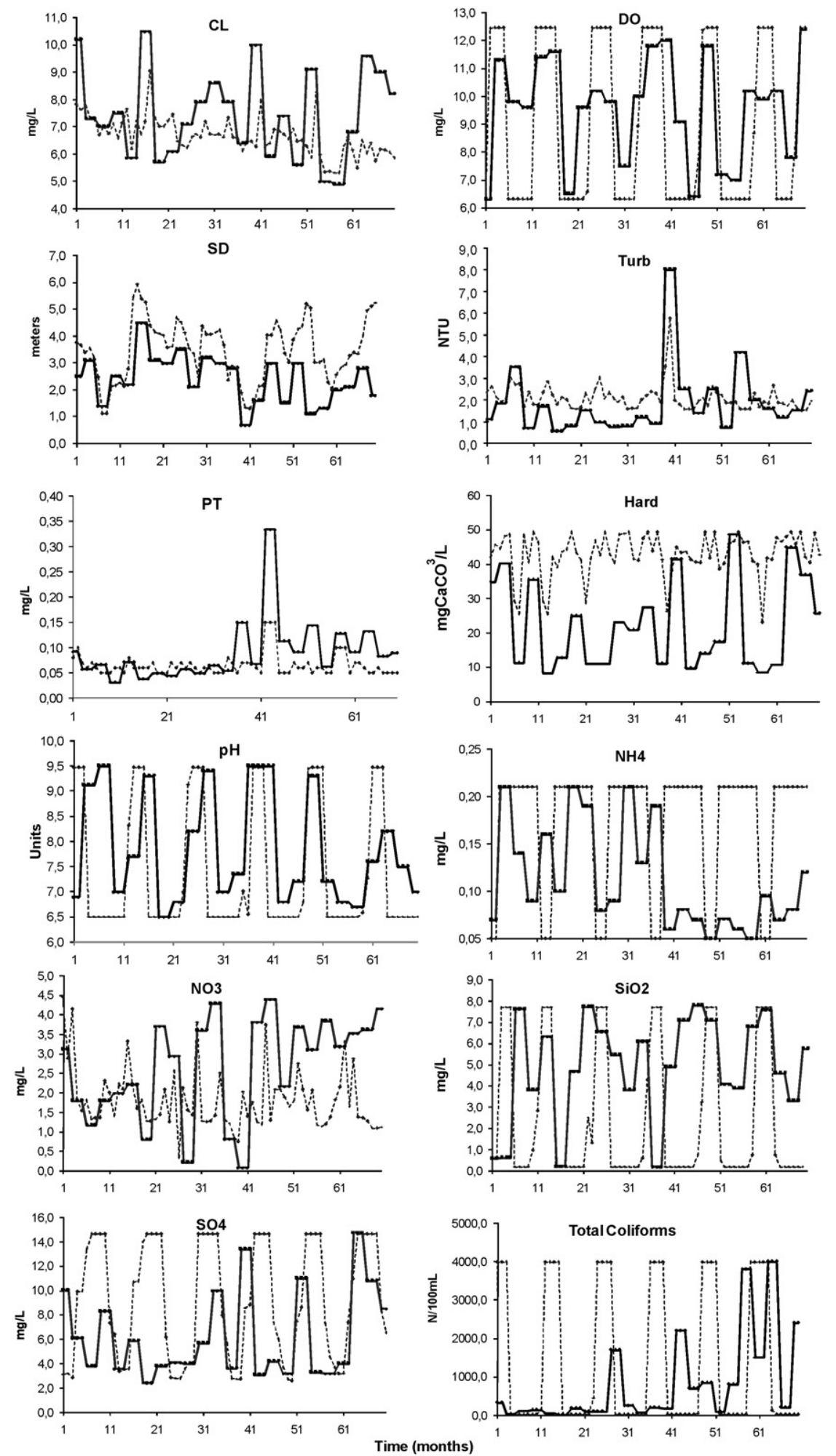

Fig. 6 - Graphical comparisons between simulations (dotted line) and observed values (solid line) for the physicochemical variables, the level 2 of the StDM model. The specification of the variable codes is expressed in Table 1. 


\section{Level 3 - Biological variables}
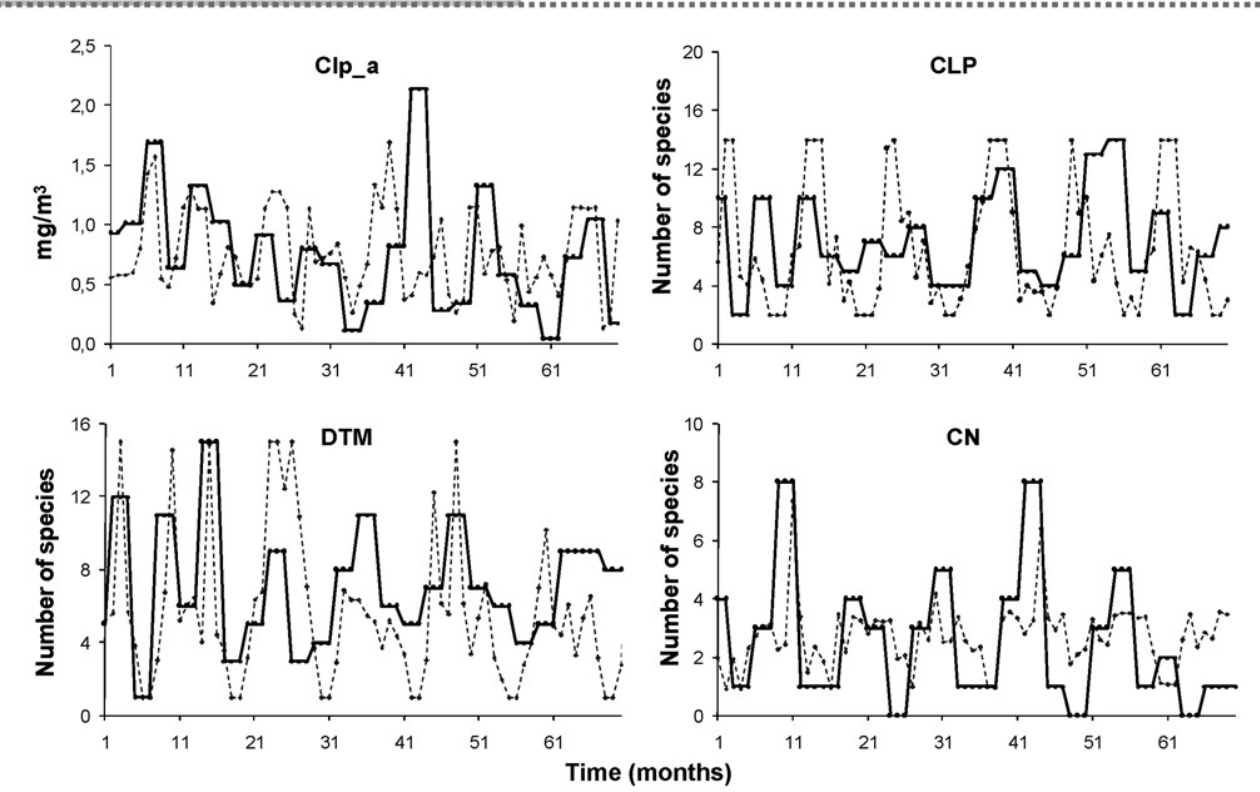

\section{Trophic state indices}

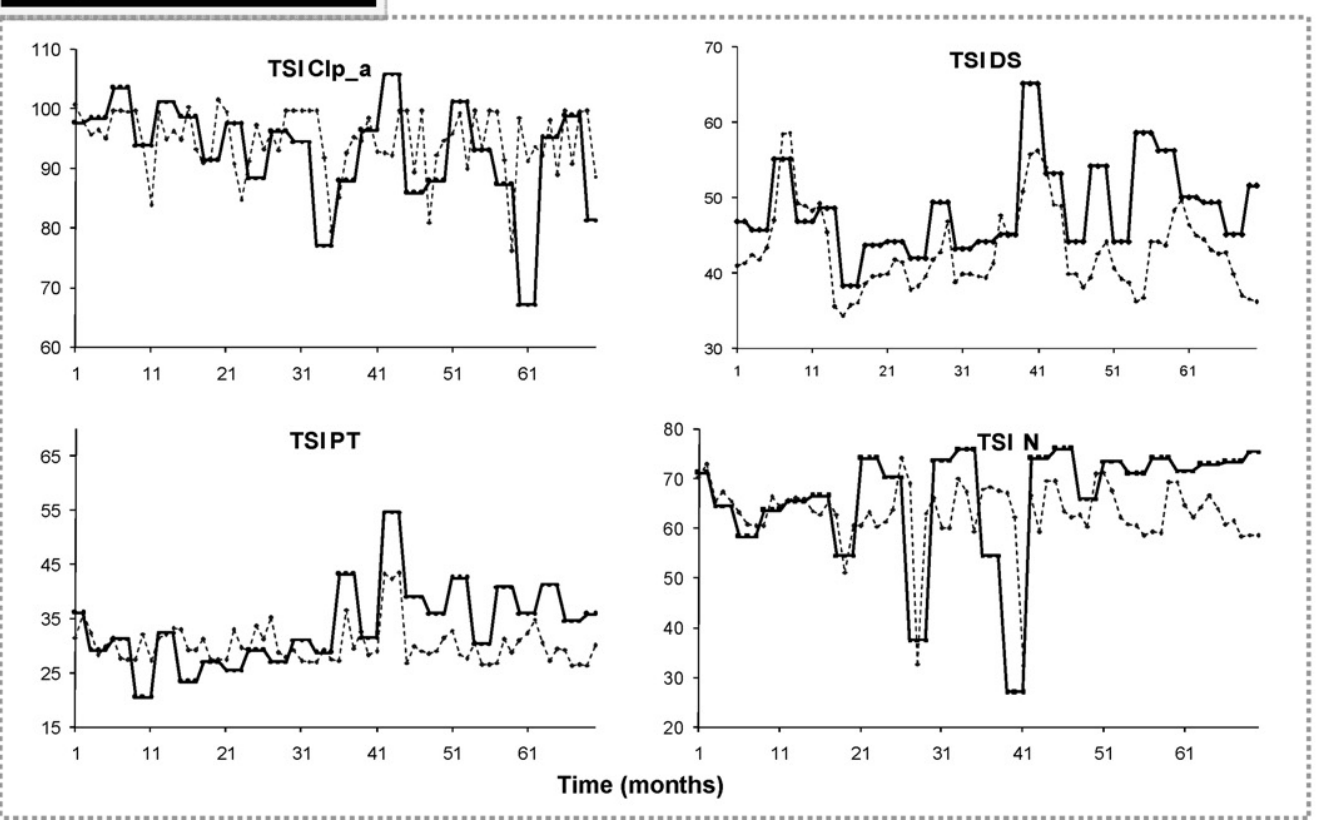

Fig. 7 - Graphical comparisons between simulations (dotted line) and observed values (solid line) for the biological variables and for the trophic status indices analysed, the level 3 of the StDM model. The specification of the variable codes is expressed in Table 1.

by meteorological and stratification-mixing processes (Wetzel, 2001). Therefore, the variation in the abundance of the total phytoplankton, represented by the chlorophyll a content simulations, shown a credible seasonal pattern with an earlier maximum occurring through spring and early summer to a maximum in July, and a second peak associated with early stages of autumnal destratification. This "dimictic" pattern is probably typical of many "mesotrophic" shallow $(<30 \mathrm{~m})$ temperate lakes and reservoirs (Reynolds, 1984; Wetzel, 2001;
Mischke, 2003). It is supposed that the two peaks reflect the coincidence of physically suitable growth conditions, with relatively high concentrations of limiting nutrients shortages of which prevent the attainment of large biomasses during the midsummer period (Reynolds, 1984; Domingues and Galvão, 2007). Seasonal succession pattern of phytoplankton in temperate dimictic reservoirs, similar to Torrão, usually involves a winter minimum with species adapted to low light and temperature, a late winter-spring and autumn peaks of 
Table 3 - Regression analysis (MODEL II) results: intercepts, slopes and respective $95 \%$ confidence limits (in parenthesis)

degrees of freedom (d.f.), coefficient of determination $\left(R^{2}\right)$, F-values and their significance level $\left({ }^{*} P<0.05 ; "{ }^{*} P<0.01\right.$;

$" P<0.001$ ) for all the observed vs. expected values of the environmental and the biological variables considered for the Torrão reservoir

\begin{tabular}{|c|c|c|c|c|}
\hline Variables & Intercept & Slope & $R^{2}$ & $F$ \\
\hline \multicolumn{5}{|c|}{ Environmental variables } \\
\hline BDO & $-890.63(-8.43 ; 14.43)$ & $635.01(-8.23 ; 8.02)$ & $<0.001$ & $<0.001$ (n.s.) \\
\hline $\mathrm{Cl}$ & $3.63(2.55 ; 4.62)$ & $0.39(0.26 ; 0.54)$ & 0.320 & $32.51^{* * *}$ \\
\hline DO & $14.77(7.60 ; 21.08)$ & $0.67(0.54 ; 0.82)$ & 0.306 & $30.48^{* * *}$ \\
\hline Hard & $37.52(34.32 ; 40.52)$ & $0.23(0.09 ; 0.37)$ & 0.137 & $10.99^{* *}$ \\
\hline $\mathrm{NH}_{4}$ & $-0.85(0.05 ; 0.34)$ & $9.06(-1.64 ; 1.04)$ & $<0.001$ & 0.13 (n.s.) \\
\hline $\mathrm{NO}_{3}$ & $1.48(0.82 ; 2.11)$ & $0.13(-0.10 ; 0.38)$ & 0.018 & 1.25 (n.s.) \\
\hline $\mathrm{pH}$ & $-5.63(-425.2 ; 0.47)$ & $1.66(0.88 ; 4.16)$ & 0.111 & $8.58^{*+}$ \\
\hline $\mathrm{PO}_{4}$ & $0.39(-4.94 ; 0.23)$ & $-10.05(-4.82 ; 160.09)$ & 0.048 & 3.49 (n.s.) \\
\hline $\mathrm{PT}$ & $0.04(0.03 ; 0.04)$ & $0.28(0.22 ; 0.34)$ & 0.554 & $85.67^{*+*}$ \\
\hline SD & $-0.28(-1.96 ; 0.75)$ & $1.55(1.12 ; 2.24)$ & 0.336 & $34.86^{* * *}$ \\
\hline $\mathrm{SiO}_{2}$ & $-15.86(-0.26 ; 73.86)$ & $4(-10.35 ; 1.51)$ & 0.028 & 1.99 (n.s.) \\
\hline $\mathrm{SO}_{4}$ & $-15.53(-0.19 ; 76.20)$ & $3.95(-10.72 ; 1.49)$ & 0.028 & 2.01(n.s.) \\
\hline TotColf & $34828.09(-2367.34 ; 4396.98)$ & $-41.24(-3.73 ; 4.61)$ & $<0.001$ & 0.042 (n.s.) \\
\hline Turb & $1.74(1.59 ; 1.88)$ & $0.17(0.09 ; 0.25)$ & 0.211 & $18.48^{* * *}$ \\
\hline \multicolumn{5}{|c|}{ Biological variables } \\
\hline CLP & $-9.86(-65.78 ;-1.57)$ & $2.32(1.15 ; 10.23)$ & 0.076 & $5.67^{*}$ \\
\hline Clp_a & $0.57(0.27 ; 0.82)$ & $0.26(-0.07 ; 0.65)$ & 0.033 & 2.37(n.s.) \\
\hline $\mathrm{CN}$ & $2.07(1.72 ; 2.39)$ & $0.25(0.13 ; 0.39)$ & 0.183 & $15.47^{* * *}$ \\
\hline DTM & $-6.22(-20.85 ;-1.04)$ & $1.67(0.94 ; 3.74)$ & 0.129 & $10.25^{* *}$ \\
\hline \multicolumn{5}{|c|}{ Trophic state indices } \\
\hline TSI Clp_a & 72.83 (50.46; 93.04) & $0.24(0.02 ; 0.48)$ & 0.060 & $4.41^{*}$ \\
\hline TSI NT & $45.71(33.99 ; 56.47)$ & $0.27(0.10 ; 0.44)$ & 0.126 & $10.00^{* *}$ \\
\hline TSI PT & $20.95(16.49 ; 25.12)$ & $0.28(0.16 ; 0.41)$ & 0.218 & $19.23^{* * *}$ \\
\hline TSI SD & $18.30(5.17 ; 28.54)$ & $0.67(0.44 ; 0.98)$ & 0.276 & $26.29^{*+* *}$ \\
\hline
\end{tabular}

diatom richness, followed rapidly by the development of green algae in the spring and finally the transition in late summer and early autumn to a peak of Cyanobacteria (Reynolds, 1984; Wetzel, 2001; Figueiredo et al., 2006). As shown in Figs. 6 and 7, the model simulations were able to capture the expected pattern of these variables in this type of reservoirs.

Overall, the performance of the present simulation results shows some realism in capturing the behavioural patterns of the studied state variables, in general with higher statistical significance between simulated and observed values. Therefore, the state variables reflect well the shift of the environmental characteristics towards known conditions and are capable of responding with credibility to the dynamics of the underlying ecological "cascade" processes, implicit in a multiscale perspective (Figs. 6 and 7). These results showed that the ecological indicators selected, as state variables, were not indifferent to changes in the ecological conditions, namely when conditions relatively unaffected by human activities were changed by man-induced disturbances. The relevant ecological drifts simulated are in agreement with real observations and other studies that investigated the biological consequences of environmental changes induced by particular anthropogenic impacts in these ecosystems.

Ecological modelling started with Lotka-Volterra and Streeter-Phelps in the 1920s, while the comprehensive use of models in environmental management started in the beginning of the 1970s. Meanwhile many models have been developed and today there are hundreds of ecological models which have been used as tool in research or environmental management (see Jørgensen, 1995, 1999, 2005). Nowadays, in monitoring and management programs, the construction of predictive tools for ecological management, namely in terms of cost and speed of reliable assessment results, is crucial. In this scope, the methodology proposed is expeditious and easily applicable to new scenario affected by gradients of changes. In a preliminary deterministic approach, the StDM was developed to validate simulations of the interactions between some relevant biological metrics (benthic macroinvertebrates) and physicochemical conditions in selected static scenarios (Cabecinha et al., 2004; Silva-Santos et al., 2006).

Although these simulations are encouraging, we believe that our present proposal will provide the development of a true management tool, namely taking into account stochastic/random phenomena that characterize the real ecological processes (Van der Meer et al., 1996). Therefore, the main improvements are the stochastic background and the multi-level connections that gives realism to the interactions considered by incorporating into the model a typical "cascade effect" observed in the dynamic of the studied ecosystems. With regard to stochastic influences, they allowed to discriminate the maximum and minimum values of each stochastic environmental variable (as suggested by Džeroski et al., 2000) and the seasonal random variation of the monthly accumulated precipitation over time. On the other hand, since the reservoirs are characterized by a high degree of heterogeneity in space and time, influenced by many interacting factors and by feedback mechanisms, this StDM multi-scale approach is particularly 
helpful to capture these multi-factor influences in natural stochastic scenarios.

When compared to other modelling methodologies, such as Artificial Intelligence (Džeroski et al., 1997; Kuo et al., 2006), the StDM is more intuitive, namely in mathematical terms, providing easy explanations for the underlying relations between independent and dependent variables and because is based on conventional linear methods that allowed a more direct development of testable hypotheses. Džeroski et al. (1997) referred that models produced in the form of rules, based on machine learning approaches, are transparent and can be easily understood by experts. The StDM exhibits these structural qualities but provides also simple, suitable and intuitive outputs, easily interpreted by non-experts (ranging from resource users to senior policy makers). Our StDM model captures the stochastic complexity of some holistic ecological trends, including true temporal and spatial gradients of stochastic environmental characteristics, which allowed the simulation of structural changes when habitat and environmental conditions are substantially changing due to anthropogenic-induced alterations.

Therefore, this study seems to represent a useful contribution for the holistic implementation of the WFD, namely for integrated assessments of the reservoirs ecological status within the environmental gradients or "data space" monitored.

\section{Conclusions}

The potential of StDM includes, at a multi-scale perspective, the interaction between ecological key-components and environmental conditions, with holistic and ecological relevance, from which management strategies can be designed to restore reservoir's biological communities that have been damaged by anthropogenic pressures, such as the eutrophication phenomena. The StDM model presented (PT103753 (pat. pend); Cabecinha et al., 2007a) could be integrated, as an exploratory tool, in the Douro's watershed management program, allowing the precise simulation of more complicated scenarios, with introduction of new mitigation measures, interactions and interferences with precise applicability conditions.

The ultimate goal is to produce simulation models that permit the creation of multi-scale patterns from changes in watersheds, whose patterns are the basis of spatially explicit ecological models (Costanza and Voinov, 2003). Therefore, we believe that StDM will provide the development of more global techniques in the scope of this research area by creating expeditious interfaces with Geographic Information Systems, which will make the methodology more instructive and intuitive to decision-makers and environmental managers.

\section{Acknowledgements}

The authors are indebted to all the colleagues from the GAPI of the University of Trás-os-Montes e Alto Douro (UTAD), namely to Dr. Jorge Machado who assisted in the StDM model patent process (PT103753, pat. pend). We would also like to thank
LABLEC for the environmental and phytoplankton data, namely to Eng. Lourenço Gil.

\section{Appendix A. Supplementary data}

Supplementary data associated with this article can be found, in the online version, at doi:10.1016/j.ecolind.2008. 05.010.

\section{R E F E R E N C E S}

Andreasen, J.K., O'Neill, R.V., Noss, R., Slosser, N.C., 2001. Considerations for the development of a terrestrial index of ecological integrity. Ecological Indicators 1, 21-35.

Bailey, R.C., Reynoldson, T.B., Yates, A.G., Bailey, J., Linke, S., 2007. Integrating stream bioassessment and landscape ecology as a tool for land use planning. Freshwater Biology 52, 908-917.

Barbour, M.T., Gerritsen, J., Snyder, B.D., Stribling, J.B., 1999. Rapid Bioassessment Protocols For Use in Streams and Wadeable Rivers: Periphyton, Benthic Macroinvertebrates, and Fish, second ed. USEPA, U.S. Environmental Protection Agency, Office of Water, Washington, DC.

Basu, B.K., Pick, F.R., 1996. Factors regulating phytoplankton and zooplankton biomass in temperate rivers. Limnology and Oceanography 41 (7), 1572-1577.

Blomqvist, P., Pettersson, A., Hyenstrand, P., 1994. Ammoniumnitrogen: a key regulatory factor causing dominance of nonnitrogen-fixing cyanobacteria in aquatic systems. Archives of Hydrobiology 132, 141-164.

Brazner, J.C., Danz, N.P., Niemi, G.J., Regal, R.R., Trebitz, A.S., Howe, R.W., Hanowski, J.M., Johnson, L.B., Ciborowski, J.J.H., Johnston, C.A., Reavie, E.D., Brady, V.J., Sgro, G.V., 2007. Evaluation of geographic, geomorphic and human influences on Great Lakes wetland indicators: a multiassemblage approach. Ecological Indicators 7, 610-635.

Cabecinha, E., Cabral, J.A., Cortes, R., 2007a. Processo de análise da qualidade da água através da projecção estocásticodinâmica de métricas de ecossistemas aquáticos numa perspectiva multi-escala. Ref.: PT103753 (pat. Pend).

Cabecinha, E., Silva-Santos, P., Cortes, R., Cabral, J.A., 2007. Applying a stochastic-dynamic methodology (StDM) to facilitate ecological monitoring of running waters, using selected trophic and taxonomic metrics as state variables. Ecological Modelling 207, 109-127.

Cabecinha, E., Cortes, R., Cabral, J.A., 2004. Performance of a stochastic-dynamic modelling methodology for running waters ecological assessment. Ecological Modelling 175 (3), 303-317.

Cabral, J.A., Rocha, A., Santos, M., Crespí, A.L., 2007. A stochastic dynamic methodology (SDM) to facilitate handling simple passerine indicators in the scope of the agri-environmental measures problematics. Ecological Indicators 7, 34-47.

Carlson, R.E., 1977. A trophic state index for lakes. Limnology and Oceanography 22, 361-369.

Carlson, R.E., 1981. Using trophic state indices to examine the dynamics of eutrophication. In: Proceedings of the International Symposium on Inland Waters and Lake Restoration. U.S. Environmental Protection Agency, (EPA 440/5-81-010), pp. 218-221.

Carlson, R.E., 1983. Discussion on "Using differences among carlson's trophic state index values in regional water quality assessment", by Richard A. Osgood. Water Resources Bulletin 19, 307-309. 
CEN/TC 230 (a). Water quality-Guidance standard for the routine analysis of phytoplankton abundance and composition using inverted microscopy. European Committee for Standardization.

CEN/TC 230 (b). Water quality-Guidance standard for physicalchemical sampling analysis.

Chaloupka, M., 2002. Stochastic simulation modelling of southern Great Barrier Reef green turtle population dynamics. Ecological Modelling 148, 79-109.

Chaves, C., Maciel, E., Guimarães, P., Ribeiro, J.C., 2000. Instrumentos estatísticos de apoio à economia: conceitos básicos. McGram-Hill, Lisboa Portugal.

Costanza, R., Voinov, A., 2003. Introduction: spatially explicit landscape simulation models. In: Costanza, R., Voinov, A. (Eds.), Landscape Simulation Modeling, A Spatially Explicit, Dynamic Approach. Springer Verlag, New York, pp. 3-20.

Danz, N.P., Niemi, G.J., Regal, R.R., Hollenhorst, T.P., Johnson, L.B., Hanowski, J.M., Axler, R.P., Ciborowski, J.J.H., Hrabik, T., Brady, V.J., Kelly, J.R., Brazner, J.C., Howe, R.W., Johnston, C.A., Host, G.E., 2007. Integrated gradients of anthropogenic stress in the U.S. Great Lakes basin. Environmental Management 39, 631-647.

Dokulil, M.T., Teubner, K., 2000. Cyanobacterial dominance in lakes. Hydrobiologia 438, 1-12.

Domingues, R.B., Galvão, H., 2007. Phytoplancton and environmental variability in a dam regulated temperate estuary. Hydrobiologia 586, 117-134.

Džeroski, S., Grbovic, J., Walley, W.J., Kompare, B., 1997. Using machine learning techniques in the construction of models. 2, data analysis with rule induction. Ecological Modelling 95 (1), 95-111.

Džeroski, S., Demšar, D., Grbovic, J., 2000. Predicting chemical parameters of river water quality from bioindicator data. Applied Intelligence 13, 7-17.

Dziock, F., Henle, K., Foeckler, F., Follner, K., Scholz, M., 2006. Biological indicator systems in floodplains-a review. International Review of Hydrobiology 91, 271-291.

Ekdahl, E.J., Teranes, J.L., Wittkop, C.A., Stoermer, E.F., Reavie, E.D., Smol, J.P., 2007. Diatom assemblage response to Iroquoian and Euro-Canadian eutrophication of Crawford Lake, Ontario, Canada. Journal of Paleolimnology 37, 233-246.

EPA, 1998. Lake and Reservoir Bioassessment and Biocretirea U.S. Environment Protection Agency. Thecnical Guidance Document. Office of water, Washington DC (EPA/841-B-98007).

Even, S., Thouvenin, B., Bacq, N., Billen, G., Garnier, J., Guezennec, L., Blanc, S., Ficht, A., Le Hir, P., 2007. An integrated modelling approach to forecast the impact of human pressure in the Seine estuary. Hydrobiologia 588, 13-29.

Figueiredo, D.R., Reboleira, A.S., Antunes, S.C., Abrantes, N., Azeiteiro, U.M., Gonçalves, F., Pereira, M.J., 2006. The effect of environmental parameters and cyanobacterial blooms on phytoplankton dynamics of a Portuguese temperate lake. Hydrobiologia 568, 145-157.

Håkanson, L., Peters, R.H., 1995. Predictive Limnology. Methods for Predictive Modelling. SPB Academic Publication, Amsterdam, 464 pp.

Heiskanen, A., Solimini, A.G., 2005. Relationships between pressures, chemical status, and biological quality elements. In: Analysis of the Current Knowledge Gaps for the Implementation of the Water Framework Directive, Joint Research Centre, European Commission.

IGEOE, Instituto Geográfico do Exército (Geografic Military Institute), Corine Land Cover 1990 and 2006 (http:// www.igeoe.pt/).

Jørgensen, S.E., 1999. State-of-the-art of ecological modelling with emphasis on development of structural dynamic models. Ecological Modelling 120, 75-96.
Jørgensen, S.E. (Ed.), 2001. Fundamentals of Ecological Modelling. third ed. Elsevier, Amsterdam.

Jørgensen, S.E., 1994. Models as instruments for combination of ecological theory and environmental practice. Ecological Modelling 75-76, 5-20.

Jørgensen, S.E., 1995. State of the art of ecological modelling in limnology. Ecological Modelling 78, 101-115.

Jørgensen, S.E., 2005. Ecological Modelling: editorial overview 2000-2005. Ecological Modelling 188 (2-4), 137-144.

Kratzer, C.R., Brezonik, P.L., Osgood, R.A., 1982. In: Kratzer, C.R., Brezonik, P.L. (Eds.), A Carlson-Type Trophic State Index for Nitrogen in Florida Lakes, vol. 18, No. 2. American Water Resources Association, pp. 343-344.

Kuo, J.-T., Wang, Y.-Y., Lung, W.-S., 2006. A hybrid neuralgenetic algorithm for reservoir water quality management. Water Research 40 (7), 1367-1376.

Lund, J.W.G., Kipling, C., Le Cren, E.D., 1958. The inverted microscope methods of estimating algal numbers and the statistical basis of estimation by counting. Hydrobiologia 11, 143-170.

McIntire, C.D., Larson, G.L., Truitt, R.E., 2007. Seasonal and interannual variability in the taxonomic composition and production dynamics of phytoplankton assemblages in Crater lake, Oregon. Hydrobiologia 574, 179-201.

Mischke, U., 2003. Cyanobacteria associations in shallow polytrophic lakes: influence of environmental factors. Acta Oecologica 24, S11-S23.

Moldan, B., Billharz, S., 1997. Sustainability Indicators: A Report of the Project on Indicators of Sustainable Development. Scientific Committee On Problems of the Environment (SCOPE), John Wiley and Sons Ltd.

Moreira, I., Ferreira, M.T., Cortes, R.M.V., Pinto, P., Almeida, P.R., 2002. Ecossistemas Aquáticos e Ribeirinhos. Instituto da Água, Ministério das Cidades. Ordenamento do Território e Ambiente, Lisboa.

Negro, A.I., De Hoyos, C., 2005. Relationships between diatoms and the environment in Spanish reservoirs. Limnetica 24 (1-2), 133-144.

Oberdorf, T., Pont, D., Hugheny, B., Chessel, D., 2001. A probabilistic model characterizing fish assemblages of French rivers: a framework for environmental assessment. Freshwater Biology 46, 399-415.

Oliveira, M.R., 1987. Phytoplankton communities structure in Portuguese reservoirs. Thesis of auxiliary investigator. National Institute of Fishing Investigation (INIP), 307 p. (in portuguese).

Podani, J. (Ed.), 2000. Introduction to the Exploration of Multivariate Biological Data. Backhuys, Leiden, p. 407.

Portuguese Weather Institute, 2007 (http://web.meteo.pt/pt/ clima/clima.jsp).

Reynolds, C.S., 1984. The ecology of freshwater phytoplankton. Series: Cambridge Studies in Ecology.

Reynolds, C.S., 1992. Eutrophication and the management of planktonic algae: what Vollenweider couldn't tell us. In: Sutcliffe, D.W., Jones, J.G. (Eds.), Eutrophication: Research and Application to Water Supply. Freshwater Biological Association, Ambleside, pp. 4-29.

Robarts, R.S., 1985. Hypertrophy, a consequence of development. International Journal of Environment Study 12, 72-89.

Santos, M., Vaz, C., Travassos, P., Cabral, J.A., 2007. Simulating the impact of socio-economic trends on threatened Iberian wolf populations (Canis lupus signatus) in North-eastern Portugal. Ecological Indicators 7, 649-664.

Santos, M., Cabral, J.A., 2003. Development of a stochastic dynamic model for ecological indicators' prediction in changed Mediterranean agroecosystems of north-eastern Portugal. Ecological Indicators 3, 285-303. 
Silva-Santos, P., Pardal, M.A., Lopes, R.J., Múrias, T., Cabral, J.A., 2008. Testing the Stochastic Dynamic Methodology (StDM) as a management tool in a shallow temperate estuary of south Europe (Mondego. Portugal). Ecological Modelling 210, $377-402$.

Silva-Santos, P.M., Pardal, M.A., Lopes, R.J., Múrias, T., Cabral, J.A., 2006. A Stochastic Dynamic Methodology (STDM) to the modelling of trophic interactions, with a focus on estuarine eutrophication scenarios. Ecological Indicators 6, 394-408.

Simboura, N., Panayotidis, P., Papathanassiou, E., 2005. A synthesis of the biological quality elements for the implementation of the European Water Framework Directive in the Mediterranean ecoregion: the case of Saronikos Gulf. Ecological Indicators 5 (3), 253-266.

Sokal, R.R., Rohlf, F.J. (Eds.), 1995. Biometry. third ed. W.H. Freeman and Company, New York.

Statzner, B., Bis, B., Dolédec And, S., Usseglio-Polatera, P., 2001. Perspectives for biomonitoring at large spatial scales: a unified measure for the functional composition of invertebrate communities in European running waters. Basic and Applied Ecology 2, 73-85.

Stevenson, J., Bailey, R.C., Harrass, M., et al., 2004. Interpreting results of ecological assessments. In: Barbour, M.T., Norton, S.B., Preston, H.R., Thornton, K.W. (Eds.), Ecological Assessment of our Aquatic Resources: Application, Implementation, and Interpretation. Stewart-Oaten A., Murdoch, SETAC, Pensacola, FL, pp. 85-111.

Van der Meer, J., Duin, R.N.M., Meininger, P.L., 1996. Statistical 821 analysis of long-term monthly Oystercatcher Haematopus 822 ostralegus counts. Ardea 84A, 39-55.

Vasconcelos, V.M., 2001. Toxic freshwater cyanobacteria and their toxins in Portugal. In: Chorus, I. (Ed.), CyanotoxinsOccurrence, Effects, Controling factors. Springer, Berlin, pp. 64-69.

Vollenweider, R.A., Kerekes, J., 1982. Eutrophication of Waters, Monitoring, Assessment and Control. OECD, Paris, 154 pp.

Wetzel, R.G., 2001. Limnology—Lake and River Ecosystems. Academic Press, San Diego, 1006 pp.

Zar, J.H. (Ed.), 1996. Biostatistical Analysis. third ed. PrenticeHall International Inc., Englewood Cliffs, New Jersey. 